\title{
DESIGN AND IMPLEMENTATION OF THE OCEANOGRAPHIC MODELING AND OBSERVATION NETWORK (REMO) FOR OPERATIONAL OCEANOGRAPHY AND OCEAN FORECASTING
}

\author{
Jose Antonio Moreira Lima' ${ }^{1}$, Renato Parkinson Martins ${ }^{1}$, Clemente Augusto Souza Tanajura², \\ Afonso de Moraes Paiva ${ }^{3}$, Mauro Cirano², Edmo Jose Dias Campos ${ }^{4}$, Ivan Dias Soares ${ }^{5}$, \\ Gutemberg Borges França ${ }^{6}$, Rodrigo de Souza Obino ${ }^{7}$ and João Bosco Rodrigues Alvarenga ${ }^{7}$
}

\begin{abstract}
This paper is concerned with the planning, implementation and some results of the Oceanographic Modeling and Observation Network (REMO) for Brazilian regional waters. Ocean forecasting has been an important scientific issue over the last decade due to studies related to climate change as well as applications related to short-range oceanic forecasts. It is a challenge to design an ocean forecasting system for a region with poor observational coverage of in situ data such as the South Atlantic Ocean. An integrated approach is proposed here in which the large-scale circulation in the Atlantic Ocean is modeled in a first step, and gradually downscaled into higher resolution regional models. This approach is able to resolve important processes such as the Brazil Current and associated meso-scale variability, continental shelf waves, local and remote wind forcing, and others. This article presents the overall strategy to develop the models using a network of Brazilian institutions and their related expertise along with international collaboration. This work has some similarity with goals of the international project Global Ocean Data Assimilation Experiment OceanView (GODAE OceanView), in which REMO takes part.
\end{abstract}

Keywords: ocean models, ocean measurements, data assimilation.

RESUMO. Este artigo apresenta o planejamento, implementação e alguns resultados da Rede de Modelagem e Observação Oceanográfica, com acrônimo REM0, para águas territoriais brasileiras. A previsão de condições oceânicas tem sido um importante tópico de pesquisa cientíica ao longo da última década, devido a estudos relacionados com mudanças climáticas assim como interesse por previsões sinóticas de curto prazo de variáveis tais como correntes marinhas e temperatura da água. É um desafio realizar o projeto de um sistema de previsão para uma região oceânica com baixa disponibilidade de medições, como 0 Oceano Atlântico Sul. Uma proposta de desenvolvimento integrado é apresentada neste trabalho, onde um modelo de circulação oceânica de todo Oceano Atlântico foi implementado como passo inicial, e gradualmente foram aninhados modelos regionais com maior resolução espacial. Este artigo apresenta a estratégia de desenvolvimento destes modelos oceânicos utilizando o conhecimento científico disponibilizado por pesquisadores de uma rede de instituições brasileiras, com eventual colaboração de pesquisadores internacionais. Esta iniciativa brasileira possui pontos comuns com um projeto de cooperação científica internacional, denominado Global Ocean Data Assimilation Experiment OceanView (GODAE OceanView), da qual a REMO faz parte.

Palavras-chave: oceanografia operacional, modelagem oceânica, sensoriamento remoto, medições oceanográficas, assimilação de dados.

\footnotetext{
${ }^{1}$ Centro de Pesquisas e Desenvolvimento Leopoldo Américo Miguez de Mello - PETROBRAS/CENPES, Av. Horacio Macedo, 950, Cidade Universitária, 21941-915 Rio de Janeiro, RJ, Brasil. Phone: +55(21) 2162-6284 or 6848 - E-mails: jamlima@petrobras.com.br, renatopm@petrobras.com.br

${ }^{2}$ Departamento de Física da Terra e do Meio Ambiente, Instituto de Física, Universidade Federal da Bahia, Campus de Ondina, Travessa Barão de Jeremoabo, s/n 40170-280 Salvador, BA, Brasil. Phone: +55(71) 3283-6685 or 6686-E-mails: cast@ufba.br, mcirano@ufba.br

3 Programa de Engenharia Oceânica - COPPE/PENO, Universidade Federal do Rio de Janeiro, Av. Horacio Macedo, 2030, Cidade Universitária, Caixa Postal 68508 , 21941-914 Rio de Janeiro, RJ, Brasil. Phone: +55(21) 2562-8754 - E-mail: afonso@oceanica.ufrj.br

${ }^{4}$ Departamento de Oceanografia Física, Química e Geológica, Instituto Oceanográfico, Universidade de São Paulo, Praça do Oceanográfico, 191, Cidade Universitária, 05508-120 São Paulo, SP, Brasil. Phone: +55(11) 3091-6597 -E-mail: edmo@usp.br

${ }^{5}$ Núcleo de Oceanografia Física, Instituto de Oceanografia, Universidade Federal do Rio Grande, Av. Itália, Km 8, 96203-900 Rio Grande, RS, Brasil. Phone: +55(53) 3233-6710 - E-mail: dsoares.ivan@gmail.com

${ }^{6}$ Departamento de Meteorologia - IGEO, Universidade Federal do Rio de Janeiro, Av. Athos da Silveira Ramos, 274, Cidade Universitária, 21941-916 Rio de Janeiro, RJ, Brasil. Phone: +55(21) 2598-9253 - E-mail: gutemberg@Ima.ufrj.br

${ }^{7}$ Centro de Hidrografia da Marinha (CHM), Seção de Modelagem Oceanográfica/REMO, Rua Barão de Jaceguay, s/n, Ponta da Armação, 24048-900 Niterói, RJ, Brasil. Phone: +55(21) 2189-3614 -E-mails: obino@smm.mil.br, alvarenga@smm.mil.br
} 


\section{INTRODUCTION}

Numerical ocean forecasting models have always lagged their meteorological counterparts. Mankind necessities associated with atmospheric weather forecasting for human safety, agriculture and aviation were probably paramount, while a large network of meteorological stations already available helped the meteorologists with better initial conditions and model reanalysis. Oceanographers, on the other hand, had to deal with lack of oceanic measurement stations and problems related with shorter spatial scales associated with their meso-scale phenomena of interest that would require higher model spatial resolution and much larger computational power. A Brazilian oceanic forecasting network should be planned using previous experience of atmospheric and oceanic numerical modeling, and it is very useful to briefly review early efforts of meteorologists to develop and implement the tools of modern numeric weather prediction.

Smagorinsky (1983) provides a good review paper on the subject, where it is described the early attempts after World War II of the Institute of Advanced Studies (IAS) in Princeton and the important contribution of a group of high-level visionary researchers such as J.G. Charney, N.A. Phillips, J.D. Von Neumann, G.D. Platzman and others. Moura (1996) also provides a good description of the initial efforts to develop numeric meteorological forecasting systems after 1942, highlighting the importance of the model proposed by Charney et al. (1950), which represented a break-through step into numerical weather prediction overcoming the problems of a pioneering work proposed by Richardson (1922, apud Moura, 1996). The advent of the Electronic Numerical Integrator and Calculator (ENIAC), initially at the U.S. Army Aberdeen Proving Ground in Maryland and later in Princeton, was also a major step to solve the proposed numerical schemes. Both authors emphasize how important was the establishment of the General Circulation Research Section in 1955, a joint venture of the U.S. Weather Bureau, Air Force and Navy, that would later become the Geophysical Fluid Dynamics Laboratory (GFDL) in 1963, initially based in Washington and moved to Princeton in 1968. Smagorinsky (1983) remembers that this laboratory considered getting involved with oceanic modeling for two reasons: techniques developed for atmospheric modeling seemed transferable to the oceans and, most important, it started to be realized that long-term evolutions of the atmosphere and its climatic properties could not be understood without understanding the interaction with the oceans.

Semtner (1995) reviews the early years of numerical ocean circulation modeling and the contribution of GFDL researchers such as K. Bryan and M.D. Cox. Their original model, presented in Bryan (1969), used explicit finite differencing scheme and the "rigid lid" approximation to eliminate high-speed external gravity waves. This model after many improvements would become the "GFDL model", a geopotential or "z-level" coordinate model that represented the workhorse of many scientific modeling studies and ocean forecasting initiatives. Its updated version, named Modular Ocean Model (MOM), was developed and it is still supported by the GFDL. Since then, a hierarchy of numerical models that simulate the ocean circulation solving primitive equations with some simplifying assumptions and prescribed forcing and boundary conditions have been developed over the last decades, generally referred as "Ocean General Circulation Models" (OGCMs). Significant contributions have been provided by an isopycnal model proposed by Bleck \& Boudra (1981), the Miami Isopycnic Coordinate Ocean Model (MICOM), that improved the representation of water masses spreading along preferential isopycnal surfaces, and a "terrain-following" or "sigma" coordinate model proposed by Blumberg \& Mellor (1987), the Princeton Ocean Model (POM), with better bottom resolution over coastal and continental shelf regions. More recent developments, relying on increasing computational power and improved physical and numerical schemes, include the Hybrid Circulation Ocean Model - HYCOM, (Bleck, 2002), and the Regional Ocean Modelling System - ROMS, (Shchepetkin \& McWilliams, 2005). These are progressively gaining widespread applications.

Today, ocean forecasting systems are gradually reaching the operational state of atmospheric forecasting models, something that was quite unthinkable a few years ago. Dombrowsky et al. (2009) reviews the main oceanic forecast systems that are operative under the Global Ocean Data Assimilation Experiment (GODAE). This project was continued by GODAE Oceanview, providing partnership and strong commitment of many research groups around the world to initialize oceanic forecasting using OGCMs on a routine basis. Many systems, such as the HYCOM/Navy Coupled Ocean Data Assimilation System (HYCOM/NCODA) in the USA, Forecasting Ocean Assimilation Model (FOAM) in Great Britain, Mercator-Ocean in France, BLUElink in Australia, Towards an Operational Prediction System for the North Atlantic European Coastal Zones (TOPAZ) in Norway and others, are providing operational oceanic forecasts using distinct data assimilation schemes, such as Ensemble Kalman filter, Optimal Interpolation (OI), and variational methods, in order to incorporate data from satellites (sea surface altimetry, sea surface temperature, surface wind, etc) and from in situ measure- 
ments (T/S profiles from Argo floats, XBTs and CTDs). After the World Ocean Circulation Experiment (WOCE) in the 1990's and with the income of the Global Ocean Observing System (GOOS), as an effort endorsed by the Intergovernmental Oceanographic Commission (IOC) and the World Meteorological Organization (WMO), new datasets have been available for oceanographers to improve model results and standards of accuracy of their forecasting capabilities. Brassington (2011) provides an overview of definitions, applications and system elements related to operational ocean forecasting systems.

Data assimilation (DA) schemes produce the so-called objective analysis by combining model outputs with in situ and remote sensed observations considering both the model and the observational errors. The analysis is used as initial condition for the forecasts. Since part of the model predictability depends directly on the quality of the initial condition, DA is a key-component of any forecasting system. DA schemes are able to incorporate data from satellites and buoys using different mathematical and computational strategies to constrain the model solution, and the analysis are also used for diagnostic studies and to complement monitoring systems. DA systems are based on optimal interpolation, Kalman filters or variational methods (Kalnay, 2003; Cummings et al., 2009). However, the realization of an assimilation system is not a trivial task, since it requires a rigid quality control system of the observational data, an estimate of the model error covariance matrix in the multivariate model space, strategies to reduce the high dimensionality of the analysis error minimization problem and deep knowledge of the model formulation and code, among other issues.

While global high-resolution operational systems are rapidly becoming available, there is still need for regional systems in which not only even higher resolutions can be attained but also particular attention can be directed to local or specific phenomena of interested. This view is acknowledged by the Oceanographic Modeling and Observation Network - REMO (acronym for "Rede de Modelagem e Observação Oceanográfica", in Portuguese), a Brazilian effort towards operational oceanography that is under construction and permanent improvement by researchers from different institutions in Brazil since 2007. This effort and preliminary results granted REMO full membership in GODAE OceanView at the end of 2010. This membership allows REMO to better participate in an international forum dedicated to planning and development of operational oceanography, including modeling, observation and data assimilation. This paper discusses the design and implementation of the first version of REMO's operational system. It also presents near future steps towards improv- ing the current ocean forecasting system. A set of companion articles in this issue will address specific research topics and results produced within REMO initially developed models.

\section{MOTIVATION}

Brazil has a very extensive continental margin that extends from approximately $4^{\circ} \mathrm{N}$ to $35^{\circ} \mathrm{S}$. The oceanic circulation along the Brazilian continental shelf and slope is directly affected by complex systems of large-scale currents associated with many distinct features, such as the Equatorial Atlantic circulation on the northern border, the South Atlantic subtropical gyre along the eastern border, and the Brazil-Malvinas Confluence on the southern border. High-resolution regional ocean models must deal with initial and boundary conditions that reproduce the effects of the large-scale circulation upon them.

The development of numerical ocean models with forecasting capabilities is a largely desired goal for countries with an extensive oceanic border such as Brazil. The main motivation factors to implement an ocean forecasting system are related with navigation safety, search and rescue operations, economic exploitation of subsea resources, fishery industry, nautical sport activities, and many others. Some motivation aspects are briefly discussed below.

Surface current maps are one of the main inputs of drift models that simulate trajectories of floating objects and human beings in a search and rescue operation, also called SAR mission. As an example, one of the most difficult SAR operations in Brazil was the accident with Air France flight AF 447 on June $1^{\text {st }}$ 2009. The airplane disappeared in the middle of the equatorial Atlantic Ocean somewhere between the Archipelago of Fernando de Noronha and the African continent. Many institutions participated in the SAR mission, including the Centro de Hidrografia da Marinha (CHM) of the Diretoria de Hidrografia e Navegação (DHN) of the Brazilian Navy. They used a SAR computational software in order to evaluate possible trajectories of debris and help setting up a search area for eventual survivors or unfortunate diseased bodies, as well as traceback the probable accident site where the plane reached the sea surface (Fig. 1). As it would be expected, surface currents field was one of most important factors to run the model, along with surface wind field.

For navigational safety purposes, the world ocean is divided into 16 areas of responsibility, called either METAREAs (for meteorological information) or NAVAREAs (for navigational warnings), each the responsibility of a National Meteorological Service (NMS). The Brazilian Navy is the responsible for the 


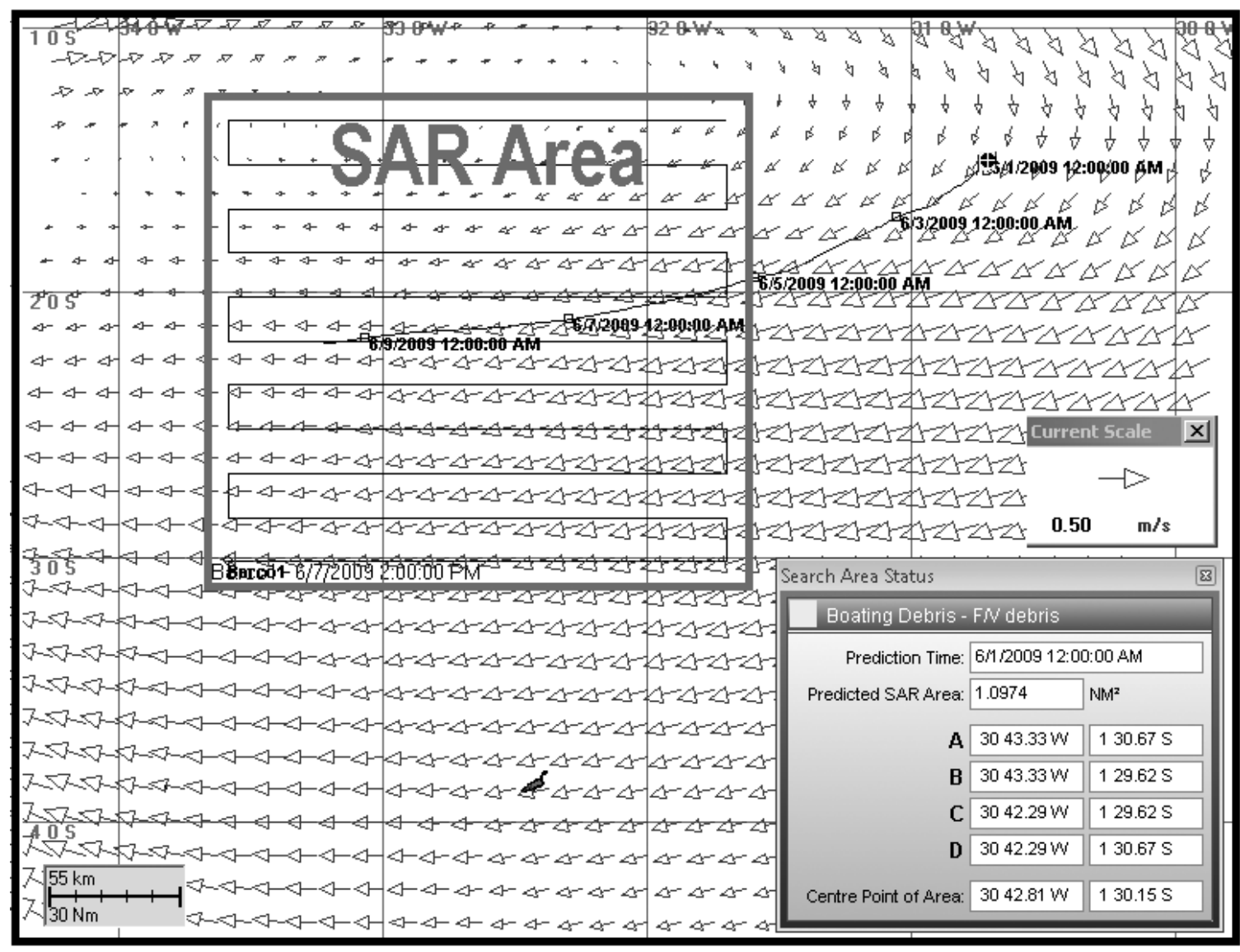

Figure 1 - Search and Rescue mission of Air France flight AF 447 airplane debris. Search area provided by the International Aeronautical and Maritime Search and Rescue (IAMSAR) method with surface current field in the background. Courtesy: CHM.

dissemination of metocean information and safety of navigation in an extensive area of the South Atlantic Ocean called METAREA $\mathrm{V}$, that covers the region between latitudes $35.5^{\circ} \mathrm{S}$ to $7^{\circ} \mathrm{N}$ and longitudes $55^{\circ} \mathrm{W}$ to $20^{\circ} \mathrm{W}$, as delimitated in Figure 4 . Thus, any ship distress informed by the Global Maritime Distress and Safety System (GMDSS) or SAR mission within this region must be accomplished with aid of the Brazilian Navy. This calls for the capability of the Brazilian Navy of both understanding and forecasting ocean currents within this domain.

Another important issue is that Brazil relies on offshore production for supply of most of its oil and gas internal consumption. About $91 \%$ of Brazilian oil production on May 2013 came from offshore oil fields (ANP, 2013). The forecast of waves, ocean currents and sub-surface thermohaline structure is very important for planning of many offshore operations, such as deep sea drilling, interventions with remotely operated vehicles, installation of subsea equipment and many other applications. For instance, the design of deep water oil production and water injection risers requires a good knowledge of current profiles (Lima et al., 2009). Figure 2 presents a schematic view of a Floating Production Storage and Offloading (FPSO) platform that has many attached risers and mooring lines, adapted from an article of Costa Filho (2005) that describes the design of this type of offshore production systems. Distinct directions of currents flowing along vertical water column affect the final configuration of the mooring lines and risers.

\section{DESIGN OF REMO FORECASTING SYSTEM}

It is always a problem for developing countries to pace up with all the new ocean technologies and computational resources required to do state-of-the-art research on ocean numerical modeling, mainly due to shortage of economic resources that could be invested into scientific grants to develop such a specialized area of science. A wise way to surpass this problem is to join efforts and bring institutions and specialized professionals to work together into a common goal of ocean modeling research establishing the basis of an operational oceanic forecasting 
system. This is the main objective of the REMO consortium, which brings together Brazilian universities, the Brazilian Navy and the Brazilian-state oil company research center to work for the common objective of developing an operational numerical oceanic forecasting system. This section will briefly outline the proposed approach and how the distinct institutions shared expertise and established goals towards a Brazilian initiative on ocean forecasting system.

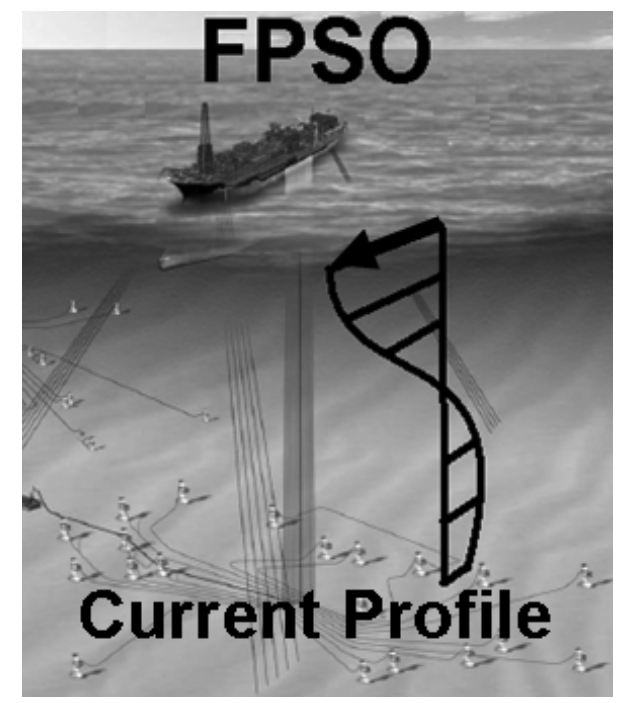

Figure 2 - Schematic view of a Floating Production Storage and Offloading (FPSO) platform with attached risers and mooring lines affected by vertical profile of ocean currents. Adapted from Costa Filho (2005). Courtesy: Petrobras.

The introduction presented examples of how specialized groups of researchers can join expertise to achieve a common objective, as was done for atmospheric weather prediction in the middle 1950 decade, and more recently for oceanic forecasting in the first decade of the XXI century. Based on these previous experiences, a group of Brazilian oceanographers and numerical modelers searched in 2006 to design a network of models and ocean observations that would permit development of an oceanic forecasting system for a region of interest in the western South Atlantic Ocean. The group included universities located on distinct regions of the Brazilian coast, what would permit widespread knowledge of regional oceanic conditions. Within REMO, Federal University of Rio Grande (FURG) represented the southern border, University of São Paulo (USP) and Federal University of Rio de Janeiro (UFRJ) represented the southeast and east regions, and Federal University of Bahia (UFBA) represented the northeast and north regions. The Centro de Hidrografia da Marinha (CHM), the Navy's Hydrographic Center, with its previous experience on marine meteorological weather prediction is responsible for operation of ocean forecast models, and PETRO-
BRAS Research Center (CENPES) provided the financial resources and centralized the efforts for the network implementation, subjected to approval of research funds by Agência Nacional do Petróleo, Gás Natural e Biocombustíves (ANP). The Instituto de Estudos do Mar Almirante Paulo Moreira (IEAPM) also gave its contribution in the initial phase. Table 1 presents the planned phases of REMO network.

REMO was designed with three main task groups: models development, observations (remote sensing and metocean measurements), and models operation, as presented in the box diagrams of Figure 3. The models development required intensive applied research at the universities, in order to implement a hierarchy of numerical grids as backbone for development of an operational modeling system for the South Atlantic, which could be used for research purposes and to support oil industry and navy operations along the Brazilian shelf. This effort includes the set up of a lower resolution large-scale grid of HYCOM that would cover both the South and North Atlantic Oceans and would provide lateral boundary conditions to a higher-resolution basin-scale grid of HYCOM centered on the METAREA V. Mesoscale versions of HYCOM and ROMS would be nested or receive boundary conditions from the METAREA V HYCOM grid.

Tasks regarding the oceanic observations and remote sensing were also detailed planned because they will provide data to be assimilated by the models as well as information to evaluate their results. Satellite remote sensing information is an essential product of this group, because models require accurate alongtrack Sea level anomaly (SLA) and Sea Surface Temperature (SST) data to constrain data assimilation schemes and provide forecast initial conditions. Ocean measurements using surface buoys and moorings are also planned to provide in situ oceanographic data. This represents an important effort to improve the coverage of oceanographic data measurements along the Brazilian continental slope.

Operational model tasks are mainly executed by $\mathrm{CHM}$ that has already extensive experience with marine weather forecasting models for METAREA V. They are running ocean models initially developed by university researchers and later on implemented in their operational computational facilities. CHM is also supporting the development of data assimilation schemes. UFBA will be running pre-operational forecasts with and without data assimilation, as redundancy and development towards the main operational system in CHM.

The main products delivered are forecasts of oceanic threedimensional fields of velocity $(\mathrm{U}, \mathrm{V})$, thermohaline structure $(\mathrm{T}, \mathrm{S})$, and sea surface elevation (EL). REMO also supports improvement 
Table 1 - Planned phases of REMO network.

\begin{tabular}{|c|c|c|c|c|c|c|c|c|c|c|c|}
\hline 2007 & 2008 & 2009 & 2010 & 11 & 2012 & 2013 & $\angle U$ & 15 & 2016 & 2017 & \\
\hline \multicolumn{4}{|c|}{ Phase 1} & \multicolumn{4}{|c|}{ Phase 2} & \multicolumn{4}{|c|}{ Phase 3} \\
\hline \multicolumn{4}{|c|}{$\begin{array}{l}\text { Build up of network infrastructure } \\
\text { (laboratories and high } \\
\text { performance computing) }\end{array}$} & \multicolumn{4}{|c|}{$\begin{array}{l}\text { Development of data assimilation } \\
\text { techniques for remote sensing } \\
\text { fields and ocean observations }\end{array}$} & \multicolumn{4}{|c|}{$\begin{array}{l}\text { Upgrading data assimilation } \\
\text { techniques using previous results } \\
\text { and extended knowledge }\end{array}$} \\
\hline \multicolumn{4}{|c|}{$\begin{array}{c}\text { Initial setup and tests of distinct } \\
\text { configurations of selected } \\
\text { numerical ocean models }\end{array}$} & \multicolumn{4}{|c|}{$\begin{array}{c}\text { Implementation of synoptic scale } \\
\text { operational ocean forecasting } \\
\text { with data assimilation }\end{array}$} & \multicolumn{4}{|c|}{$\begin{array}{l}\text { Upgrading the ocean hindcast } \\
\text { databases using improved } \\
\text { assimilation techniques }\end{array}$} \\
\hline \multicolumn{4}{|c|}{$\begin{array}{l}\text { Capacitate human resources } \\
\text { to pursue specialized research } \\
\text { in ocean modeling }\end{array}$} & \multicolumn{4}{|c|}{$\begin{array}{l}\text { Build up of inicial ocean hindcast } \\
\text { databases using selected models } \\
\text { (hydrodynamic ocean bases) }\end{array}$} & \multicolumn{4}{|c|}{$\begin{array}{l}\text { Consolidation of an integrated } \\
\text { ocean forecasting system with } \\
\text { contribution of public or private }\end{array}$} \\
\hline
\end{tabular}

\section{Oceanographic Modeling and Observation Network (REMO)}

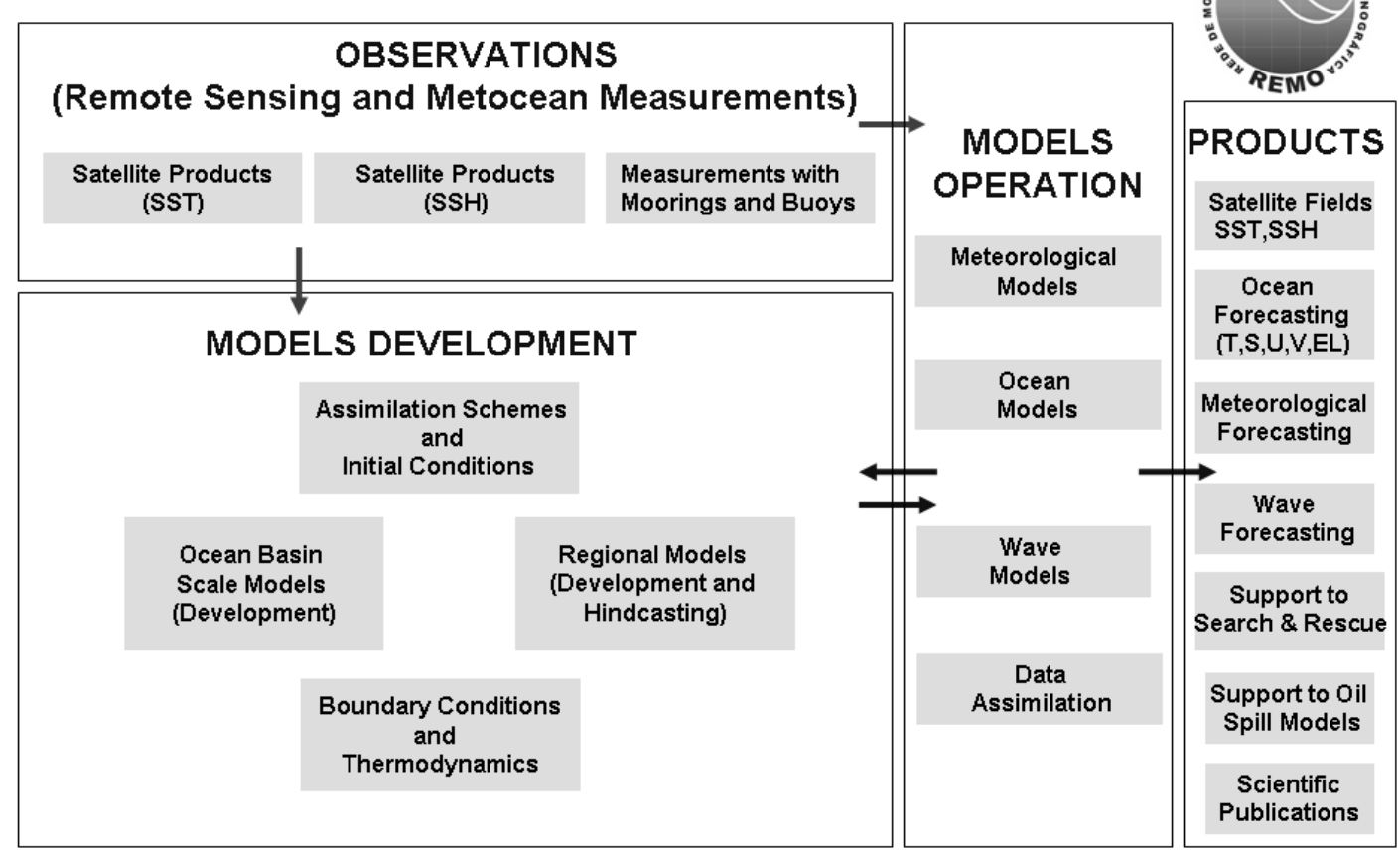

Figure 3 - Task groups (models development, operation, observations) and products to be delivered by the oceanic forecasting system as designed by REMO network. Logos identify institutions involved with each task.

of atmospheric model forecasts to provide better meteorological forcings to ocean circulation and wave models driven by the resulting wind fields. The products are used to support many activities, as described in the motivation section, such as search and rescue operations, input to oil spill simulation models, navigational safety bulletins and others applications. It is also expected to provide results for scientific publications and to support academic activities on physical oceanography and related fields.

\section{BASIN SCALE AND REGIONAL OCEAN MODELING}

The basic hierarchy of model configurations for REMO network includes a basin scale eddy-permitting version of HYCOM, nowadays with $1 / 4^{\circ}$ horizontal resolution but already planned to use higher horizontal resolution, that covers both the South and North Atlantic Oceans and provides boundary conditions for an eddy-resolving version of the same model, with $1 / 12^{\circ}$ horizontal 
resolution, covering the METAREA V ocean area (Fig. 4). Regional configurations, with $1 / 24^{\circ}$ and higher horizontal resolutions are then nested for specific domains of interest, using versions of HYCOM, ROMS and other available models. There are three planned regional sub-domains: a south-southeast (SSE) grid, an east (E) grid and a north-northeast (NNE) grid.
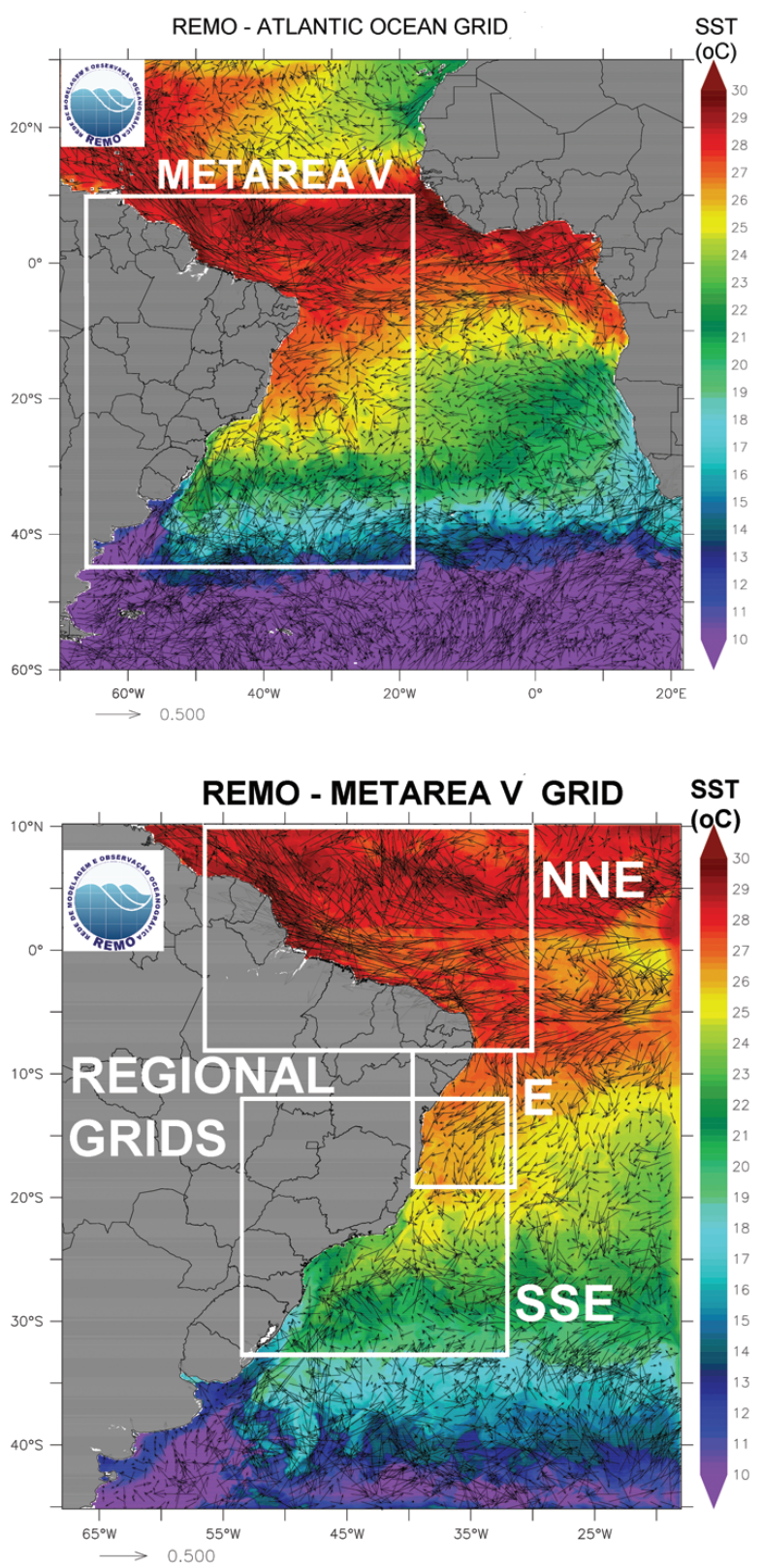

Figure 4 - REMO models nesting configuration, showing the eddy-permitting Atlantic basin domain (up panel), the eddy-resolving METAREA V domain, and some examples of higher resolution regional domains (down panel).

In the basin scale configuration, model domain was designed in order to place the boundaries far away from the area of interest. The north domain extends to $50^{\circ} \mathrm{N}$, where the boundary is closed and a relaxation zone to climatology forces the vertical shear. This approach, and in particular this latitude, have been shown in previous simulations (Paiva et al., 2000; Paiva \& Chassignet, 2001) to provide good results with isopycnal models. Mediterranean inflow is simulated, also through a relaxation zone around Gibraltar, in order to maintain salt balance in long-term simulations together with river outflow, which is implemented via a precipitation equivalent. In the southern domain, inflow and outflow conditions in the Drake and south of Africa forces the Antarctic Circumpolar Current, and a simple ice model is implemented. The model was spun-up under National Center for Environmental Prediction (NCEP)/National Center for Atmospheric Research (NCAR) synoptic atmospheric forcing for 30 years. Boundary conditions were then provided for a 7-year high-resolution simulation within the METAREA V domain, carried up to 2009. From this point on simulations were carried out in both domains in an assimilative mode. Details of the model configuration, discussion of its main results and of the strengths and weakness of this approach are presented in a companion paper (Gabioux et al., 2013). While the METAREA $V$ and the regional versions can be nested using results from simulations performed elsewhere if desired (e.g., global runs), our present approach, which takes into account the available computational power within REMO network, is desirable in order to provide necessary autonomy to the system.

The METAREA V South Atlantic nested grid is showed in the right panel of Figure 4. Its domain extends from $10^{\circ} \mathrm{N}$ to $45^{\circ} \mathrm{S}$ and from $18^{\circ} \mathrm{W}$ to $68^{\circ} \mathrm{W}$. It is implemented using a $1 / 12^{\circ}$ horizontal resolution HYCOM model with 21 vertical $\sigma_{\theta}$ layers. Initially, the grid was warmed up with a 10-year simulation with COADS climatological forcing and later with a 7-year run from 2003 to 2009 using NCEP/NCAR 6-hour reanalysis forcing. Right now, daily forecasts are being done at $\mathrm{CHM}$ using $0.1^{\circ}$ horizontal resolution HRM synoptic forecasts with the Cooper \& Haines (1996) assimilation scheme taking SSH from the HYCOM/NCODA analysis since November 2009.

Regarding the regional ocean modeling component, efforts are concentrated into numerical grids that would solve particular details of ocean circulation at some regions of the Brazilian shelf. The first implemented regional grid was a south-southeast (SSE) sub-domain with high resolution $1 / 24^{\circ}$ horizontal grid HYCOM model using 21 vertical $\sigma_{\theta}$ layers, and horizontal domain from $12^{\circ} \mathrm{S}$ to $32^{\circ} \mathrm{S}$ and from $34^{\circ} \mathrm{W}$ to $54^{\circ} \mathrm{W}$ (Fig. 5, left panel). The lower boundary was placed at $32^{\circ} \mathrm{S}$ to avoid perturbations of the Brazil and Malvinas Currents Confluence further south. The objective of this regional grid was to cover the main Brazilian 

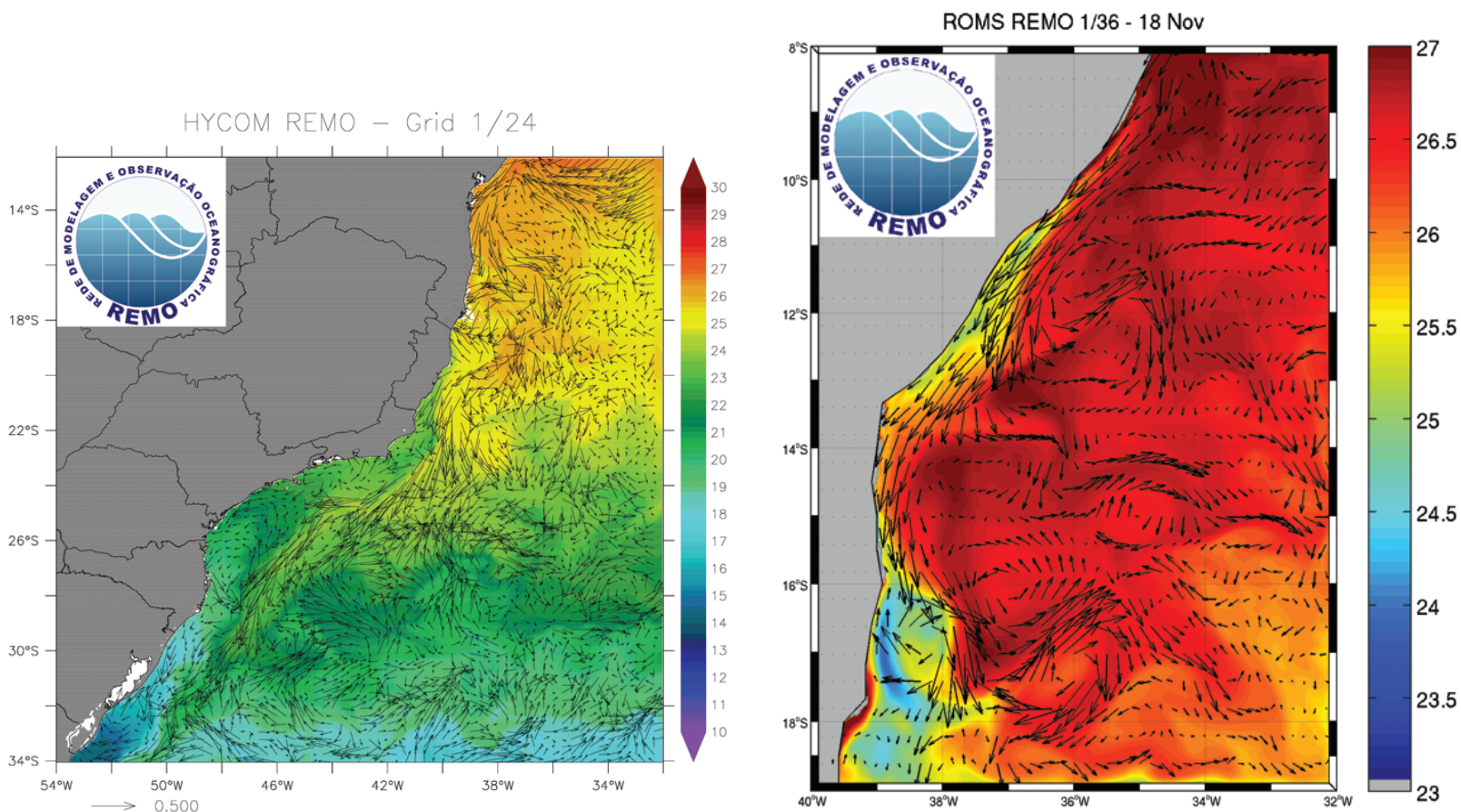

Figure 5 - South-southeast Brazilian shelf regional grid covering an oceanic area that comprises Espírito Santo, Campos and Santos offshore sedimentary basins (left panel). East Brazilian shelf regional grid covering Camamu, Almada and Jequitinhonha basins (right panel).

offshore production regions (Espírito Santo, Campos and Santos basins). The model was warmed up with a 6 -year simulation from 2004 to 2009 using analyses from the NCEP Global Data Assimilation System (GDAS). A similar SSE grid was also setup with ROMS using the same horizontal resolution but higher vertical discretization (32 s-levels) in order to compare results and evaluate strategies of data assimilation with distinct models. The second implemented regional sub-domain was an east (E) domain with high resolution $1 / 36^{\circ}$ horizontal SSE grid ROMS model using $32 \mathrm{~s}$-levels, and a horizontal domain extending from $8^{\circ} \mathrm{S}$ to $19^{\circ} \mathrm{S}$ and from $32^{\circ} \mathrm{W}$ to $40^{\circ} \mathrm{W}$ (Fig. 5, right panel). The upper boundary will be extended further northward in order to intersect with the N-NE grid. A comprehensive description of the east grid and its results are provided at Amorim et al. (2013).

There are distinct metrics to evaluate results of numerical ocean forecast models. Many tests are being considered to evaluate the model results and compare with available measured oceanographic data. One of the best measurement programs in the Atlantic Ocean is the Prediction and Research Moored Array in the Tropical Atlantic (PIRATA), part of the Brazilian component of GOOS-Brazil. Figure 6 presents a comparison of $15^{\circ} \mathrm{C}$ and $25^{\circ} \mathrm{C}$ isotherms depths from the $1 / 4^{\circ}$ horizontal resolution HYCOM model with an equatorial PIRATA buoy moored at $0^{\circ} \mathrm{N}$ and $35^{\circ} \mathrm{W}$ and a tropical PIRATA buoy moored at $10^{\circ} \mathrm{S}$ and $10^{\circ} \mathrm{W}$.

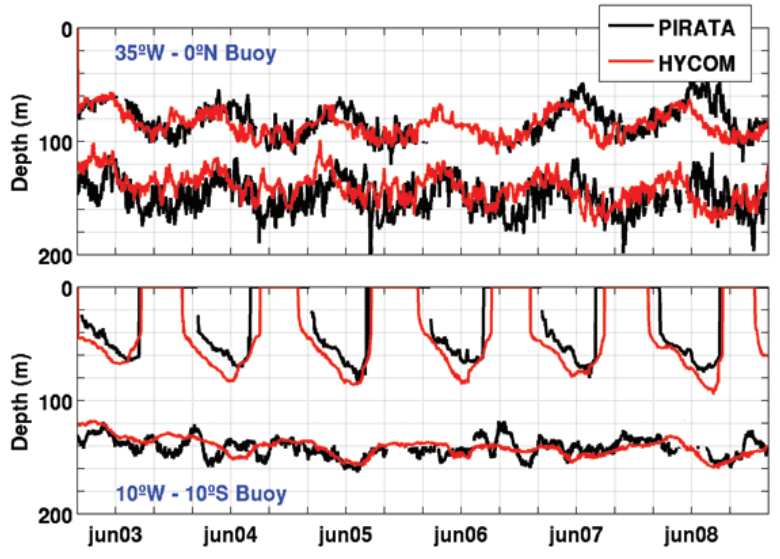

Figure 6 - Comparison of $15^{\circ} \mathrm{C}$ and $25^{\circ} \mathrm{C}$ isotherm depths of the $1 / 4^{\circ}$ horizontal resolution HYCOM model and two PIRATA buoys (upper panel shows data from an equatorial buoy and lower panel presents data from a tropical buoy).

Paiva et al. (2012) made the first version of a hindcast hydrodynamic database integrating the $1 / 24^{\circ}$ horizontal resolution south-southeast (SSE) regional HYCOM model for seven years from 2004 to 2010, using Cooper \& Haines (1996) assimilation scheme for SLA extracted from AVISO altimetry gridded fields, synoptic atmospheric forcings from NCEP Reanalysis 2 fields, and local tidal forcing using the eight main harmonic components extracted from TPX07.2 model. The results of tidal elevation show a very good agreement with measured data from 
the Global Level Ocean Observing System (GLOOS-Brazil) in stations located inside the grid domain. As an example, the model sea surface elevation was able to capture both astronomical and meteorological sea surface fluctuations at Macaé, Rio de Janeiro (Fig. 7).

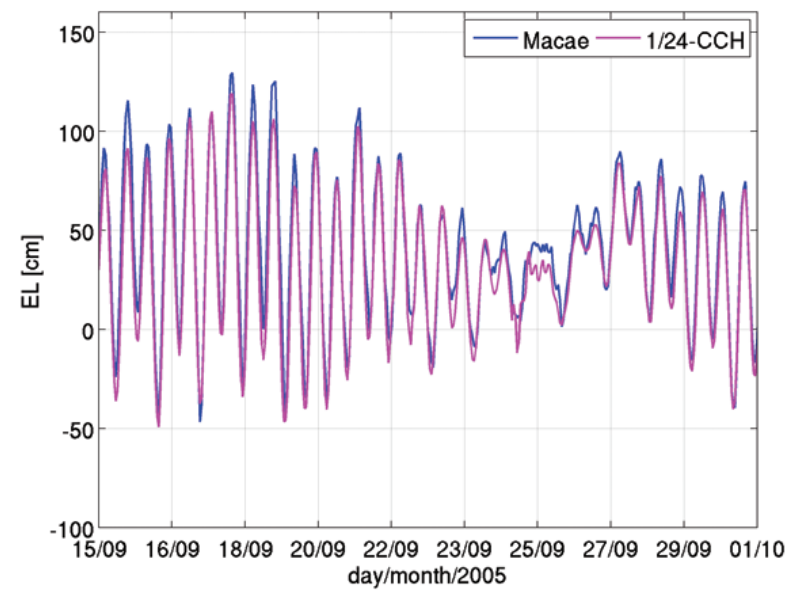

Figure 7 - Sea surface elevation of $1 / 24^{\circ}$ degree SSE HYCOM model (magenta line) and measured GLOOS data at Macaé, RJ (blue line) from September $15^{\text {th }}$ to October $1^{\text {st }} 2005$.

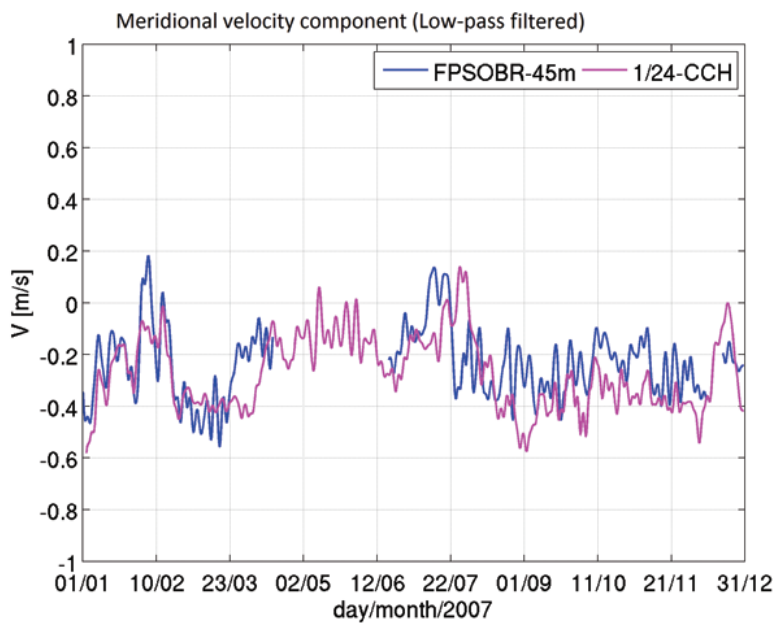

Figure 8 - Meridional component of the velocity of $1 / 24^{\circ}$ horizontal resolution SSE HYCOM (magenta line) and measured current data at location FPSO-BR (offshore Cape São Tomé, 1260-m water depth, measurement level -45 m) from January $1^{\text {st }}$ to December $31^{\text {st }} 2007$.

The BC flow at the vicinity of Cape São Tomé is mainly southward due to the northward alignment of bathymetric contours in the region, but it is also affected by large meanders or eddies (Silveira et al., 2008) associated with baroclinic instability mechanisms. The time series of meridional component of the velocity of $1 / 24^{\circ}$ horizontal resolution HYCOM obtained by Paiva et al. (2012) showed a good agreement with measured current data at location of the production platform FPSO-BR (located at $21.9322^{\circ} \mathrm{S}, 38.8183^{\circ} \mathrm{W}$ ) in a local depth of $1260 \mathrm{~m}$. Figure 8 presents modeled and measured time series at level $45 \mathrm{~m}$ below the surface for a one-year time interval of available data (2007). The directional scatter diagrams of measured current data at this site and modeled results also shows good agreement with dominant currents flowing southward with similar velocity ranges (Fig. 9).
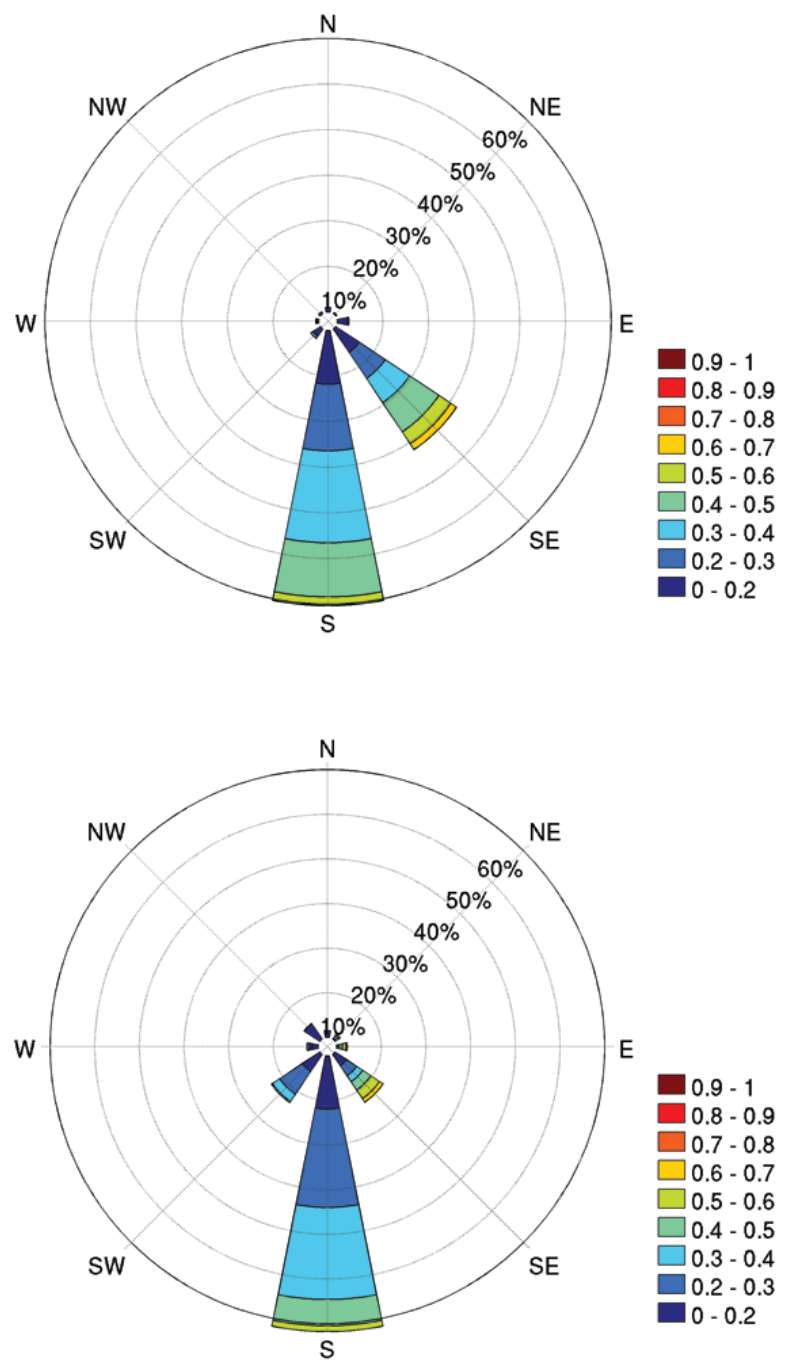

Figure 9 - Directional scatter diagrams of measured current data at location FPSO-BR (offshore Cape São Tomé, 1260-m water depth, measurement level $45 \mathrm{~m}$, up panel above) and $1 / 24^{\circ}$ horizontal resolution SSE HYCOM (down panel above) from January $1^{\text {st }}$ to December $31^{\text {st }} 2007$.

\section{DATA ASSIMILATION DEVELOPMENT APPROACH}

One of the long-term objectives of the REMO consortium is to implement an operational predictive model with a multivariate ocean data assimilation system. The assimilation of geophysical data into dynamical models of the ocean has become one of the most attractive scientific areas during the last decade. This 
was mostly caused by the demands on improvements of climate predictability, increase in computational resources, and substantial developments in the global ocean observational system (Clark et al., 2009; Cummings et al., 2009). The main goal of data assimilation has historically been to improve short-range forecasts, since model predictability is strongly dependent on the initial condition (e.g., Kalnay, 2003). However, data assimilation has other important applications too. For instance, it is used in long-term integrations to produce reanalysis for climate studies and in support and complement to monitoring systems.

Among the simpler methods are the ones in which both the model error covariance matrix and the gain matrix are prescribed, such as in the Bergthorsoon and Doos method (Daley, 1991) and simplifications of the optimal interpolation scheme (e.g. Derber \& Rosati, 1989). Among the more complex methods are the four-dimensional variational method (4D-Var) and the Ensemble Kalman filter. The former requires the construction of a linear adjoint version of the model and a complex iterative process with forward and backward integrations in time to minimize the model error trajectory along an observational time window (Weaver et al., 2003; Moore et al., 2011). The latter uses the model equations to predict the model error covariance matrix and find the optimal Kalman gain matrix and the optimal analysis in each assimilation step (Ghil \& Malanotte-Rizzoli, 1991; Cohn, 1997; Evensen, 2003). However, the realization of both of these approaches is very difficult. For the 4D-Var, the calculation of each analysis may take tens of iterations, high computational cost - since each iteration consumes approximately same computing time as two model forecasts in the observational window -, and the construction of the adjoint version of the nonlinear model is not trivial. The Ensemble Kalman filter requires an ensemble forecasting system with tens of members, the inversion of matrices $\mathrm{O}(\mathrm{N})$, where $\mathrm{N}$ is the number of the observations, commonly $0\left(10^{6}-10^{7}\right)$, and several numerical techniques to enable its realization.

Data assimilation efforts under REMO considered several methods discussed in the previous paragraph and two main methodologies were initially selected considered for operational purposes. The first is based on the work of Mellor \& Ezer (1991) and Ezer \& Mellor $(1994,1997)$, hereafter referred to as E\&M (Oliveira, 2009). This approach was implemented into HYCOM in operational mode in February 2012. The second is the Ensemble Optimal Interpolation (EnOI) (Evensen, 2003; Xie \& Zhu, 2010). It is planned to substitute the E\&M scheme in the operational system by the end of 2013. However, other techniques are also under investigation. One is a version of the Kalman Filter based on the Fokker-Planck equation (Belyaev et al., 2001; Tanajura \& Belyaev, 2009), and the other is the 4D-Var. The former was already applied into HYCOM (Belyaev et al., 2012) and the latter is available for ROMS. For specific application with HYCOM, an optimal interpolation scheme and the Cooper \& Haines (1996) scheme have also been employed to assimilate satellite alongtrack SLA (Lima \& Tanajura, 2013; Tanajura et al., 2013).

In the E\&M approach, synthetic data of vertical profiles of temperature and salinity are calculated from previously computed correlation factors considering the three-dimensional temperature and salinity fields, SST and SSH. Since the correlation factors are computed in $z$-space and HYCOM is a hybrid coordinate model, a strategy to transform the model variables from hybrid-coordinate to $z$-coordinate space was developed using Lagrangian multipliers to constrain the mean temperature and salinity in each model layer (Oliveira, 2009). The Ol scheme was then applied to assimilate the synthetic data of potential temperature and density. The analyses were transformed back to hybrid coordinates and blended to other model variables using routines already available in HYCOM to produce the model initial condition for the next assimilation cycle.

Using a twin approach, Oliveira (2009) performed assimilation experiments in $z$-coordinates over the Southwest Atlantic $\left(15^{\circ} \mathrm{S}-35^{\circ} \mathrm{S}, 32^{\circ} \mathrm{W}-56^{\circ} \mathrm{W}\right)$ to show that the E\&M method was correctly implemented in HYCOM and was able to constrain the ocean state towards the given data. The twin experiment was conducted by first performing a one-year run forced with Comprehensive Ocean-Atmosphere Data Set (COADS) atmospheric fields, after a 30-year spin-up. Model results from day 201 until day 321 were saved to serve as "reality" and to provide SSH and SST as pseudo-data for the data assimilation run. Then, four 120-day runs from day 201 until 321 forced with the COADS climatological fields for the corresponding period were performed with the same initial condition taken on day 21 of the one-year run. The first run was a control run without assimilation, in which only the atmospheric forcing was able to modify the ocean state. The second run was an assimilation run, in which the model state was altered by the atmospheric forcing and by assimilation of SST every 5 days. The third and forth runs were similar to the second run, but only SSH and both SST and SSH, respectively, were given as data to the E\&M scheme. Several evaluations were made. It was clear that the assimilation runs were quite distinct from the control run. In about a month, the differences were already substantial. The vertical profile of the root mean square error (RMSE) of the temperature with respect to "reality" was calculated for each run considering the 120 days of simulation. 
The best results were attained when both SSH and SST (fourth run) were used in the E\&M scheme, as shown in Figure 10. The largest error of the control run was about $2^{\circ} \mathrm{C}$ at $400 \mathrm{~m}$ depth. The largest error of the fourth run was about $1^{\circ} \mathrm{C}$ around $50 \mathrm{~m}$ depth. These errors are related to misrepresentations of the mixed layer depth and of the thermocline structure.

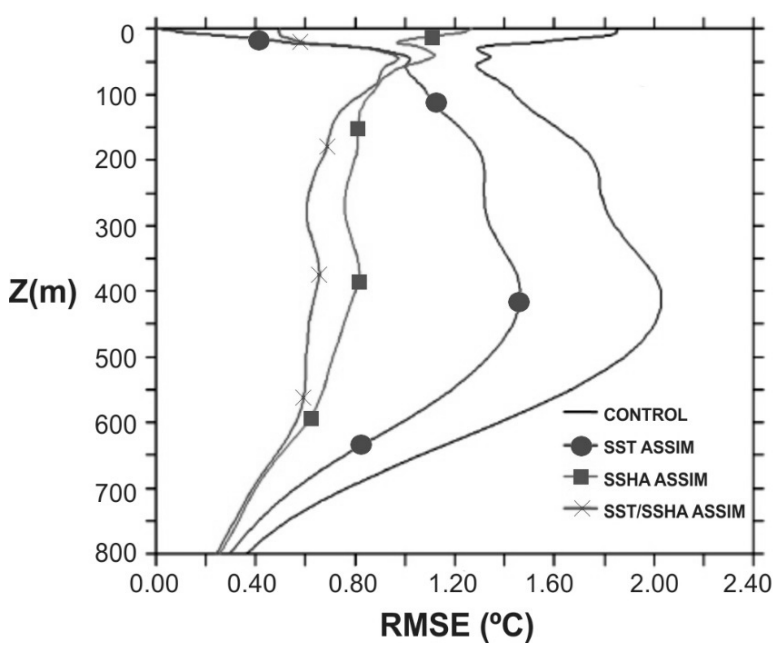

Figure $\mathbf{1 0}$ - Vertical profiles of RMSE of temperature $\left({ }^{\circ} \mathrm{C}\right)$ for the runs without assimilation (continuous line); with assimilation considering only SST (line with squares), with assimilation considering only SSH (line with circles) and with assimilation considering both SST and SSH (line with diagonal cross). Modified from Oliveira (2009).

The work by Oliveira (2009) was further developed in CHM under REMO cooperation. The correlations between SST, SSH and the vertical profiles $T$ and $S$ were recalculated taking the analysis of the HYCOM/NCODA system for the HYCOM with $1 / 12^{\circ}$ horizontal resolution. The inputs to the system are SSH and SST from the HYCOM/NCODA analysis. This specific E\&M based system was implemented in operational mode by $\mathrm{CHM}$ researchers starting in February 2012.

The first steps toward the EnOl started with the implementation of a simplified Ol scheme - with prescribed model error covariance matrix - to assimilate along-track SLA data from Jason-1 and Jason-2 satellites. In this scheme, after having the SLA analysis, the mean SSH is added to it to produce an SSH field and feed the E\&M or the Cooper \& Haines (1996) scheme. The latter corrects the model layer thicknesses to match a given SSH field. This method is able to make substantial changes in the upper ocean circulation and on the thermocline structure, but not on the overall thermohaline profile. More details on the assimilation of SLA with OI and the use of the Cooper \& Haines scheme can be found in this edition (Lima \& Tanajura, 2013; Tanajura et al., 2013)
Unless higher performance computational resources are available, EnOI is expected to be the main data assimilation method employed into REMO operational models in the near future. The method is discussed in Evensen (2003) and in Sakov et al. (2012), but for HYCOM it follows very closely the work by Xie \& Zhu (2010) and Xie et al. (2011). Today, the method is applied separately to assimilate T-S profiles from Argo floats, along-track satellite SLA data and SST data into HYCOM. Several tests were already performed and its implementation should be consolidated at the end of 2013, including a parallelized version of the current sequential code. In the EnOI approach, an ensemble of model states is used to estimate the model error covariance matrix and the 0 f formula is applied to calculate the optimal analysis. The ensemble members are chosen considering the ocean high frequency intraseasonal variability, so that a different error covariance matrix is calculated for each assimilation date. The members are selected from a long-term free model run without assimilation performed $a$ priori. A simulation from 1998 until 2010 with daily outputs has been used to provide a set of states for the ensemble and used in the computational implementation of the method into HYCOM $1 / 4^{\circ}$ horizontal resolution, which covers the whole Atlantic from $78^{\circ} \mathrm{S}$ to $50^{\circ} \mathrm{N}$.

In the first tests to assimilate T-S from Argo, different numbers of ensemble members were employed, from 30 to 132. The analysis was sensitive to the increase of ensemble members from 30 until 100 members. After that, only small differences were observed. In REMO, at least 100 members will be used in EnOI. As an example, results from an experiment with 132 members are presented. Argo data was assimilated each 3 days from 1 January until 31 March 2010, considering an observational window of also 3 days. A weight function is applied in the observational error matrix to consider larger errors for the older data with respect to the assimilation time. The model was forced by analyses from NCEP GDAS, namely, short and longwave fluxes, 2-m temperature, 2-m mixing ratio, 10-m winds and precipitation minus evaporation each $6 \mathrm{~h}$ along the integration. A total of 3647 T-S vertical profiles were assimilated. Following Xie \& Zhu (2010), the observed T-S profiles and the model isopycnic coordinates were used to produce a synthetic "observed" layer thickness profile. These thicknesses were assimilated to change the model layer thicknesses and the horizontal velocity. After that, $T$ and $\mathrm{S}$ were assimilated separately, but in the isopycnic layers, a choice was made to maintain the analysis of $S$ and diagnose $T$, as in Xie \& Zhu (2010). In the assimilation run, T-S produced an analysis that was used as initial condition for the following 
integration period. In the control run, no assimilation was employed. The T and S RMSE for $24 \mathrm{~h}$ "forecasts" along the experiment were calculated with respect to Argo profiles. Therefore, this evaluation was performed with independent data, i.e., the RMSE of the $24 \mathrm{~h}$ "forecasts" was calculated with the Argo data that were used only in the next assimilation cycle. The results show that EnOI could substantially reduce the RMSE of $T$ and $S$ from surface until $2000 \mathrm{~m}$, i.e., until where Argo data are available (Fig. 11). The errors are reduced by about $0.3-0.4^{\circ} \mathrm{C}$, and by more than 0.05 in psu. It is clear that despite the benefits of the assimilation, the control run errors limit a more effective result of the assimilation run. Longer experiments are under way and they should produce larger reduction of the errors.
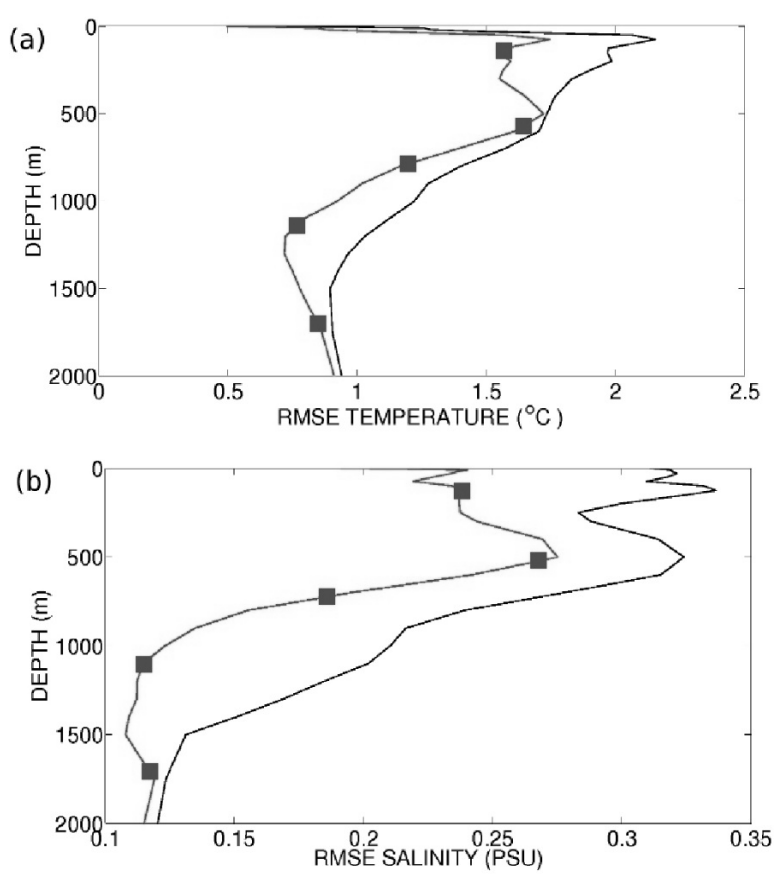

Figure 11 - Vertical profiles of RMSE with respect to Argo data for (a) temperature $\left({ }^{\circ} \mathrm{C}\right.$ ) and (b) salinity (psu) for $24 \mathrm{~h}$ forecast from January $1^{\text {st }}$ until March $31^{\text {st }} 2010$ produced by the assimilation run (line with rectangles) and the control run (continuous line).

EnOI was also used to assimilate along-track SLA data from Jason-1 and Jason-2 satellites. The data were adjusted using the technique proposed in Tanajura et al. (2013) in this edition, in which the adjusted SLA mean and the model SLA mean along each satellite track were the same. Therefore, the model SLA is corrected only locally, by imposing troughs and ridges according to the modified data, without including in the analysis well-known biases that exist between the model SLA and the observed SLA. A free model run forced with NCEP GDAS reanalysis 2 from 1 January 1998 until 31 December 2010 produced the model states for the ensemble and the initial condition for several experiments. An experiment was performed from 1 January to 31 March 2011 in which HYCOM was forced with NCEP reanalysis 2, without assimilation and with assimilation each 3 days taking a 24-hour observation window. The results showed a reduction of the centered RMSE of the $24 \mathrm{~h}$ SLA "forecast" calculated with respect to AVISO $1 / 3^{\circ}$ horizontal resolution gridded data from about $0.09 \mathrm{~m}$ to about $0.075 \mathrm{~m}$ (Fig. 12). In addition, there was a substantial improvement in the correlation from less than 0.3 in the control run to about 0.55 in the $24 \mathrm{~h}$ forecast of the assimiIation run in only 30 assimilations during the 90 day integration. The standard deviations of the model control run and of the assimilation run are similar to each other, around $0.06 \mathrm{~m}$, but smaller that the $0.09 \mathrm{~m}$ of the observations. This indicates that the model $1 / 4^{\circ}$ horizontal resolution is not enough to capture the observed variability of SLA. HYCOM with higher horizontal resolutions, namely $1 / 12^{\circ}$ and $1 / 24^{\circ}$, are also running in operational mode in CHM. As soon as the EnOl is consolidated, it will also be implemented in these other grids. Other experiments will be done in which the observational window will be increased to $48 \mathrm{~h}$. This increase, combined with improvements in horizontal resolution and longer integrations, should produce more effective reduction of the error and increase in the correlation, as well as improvement in the ocean circulation forecast.

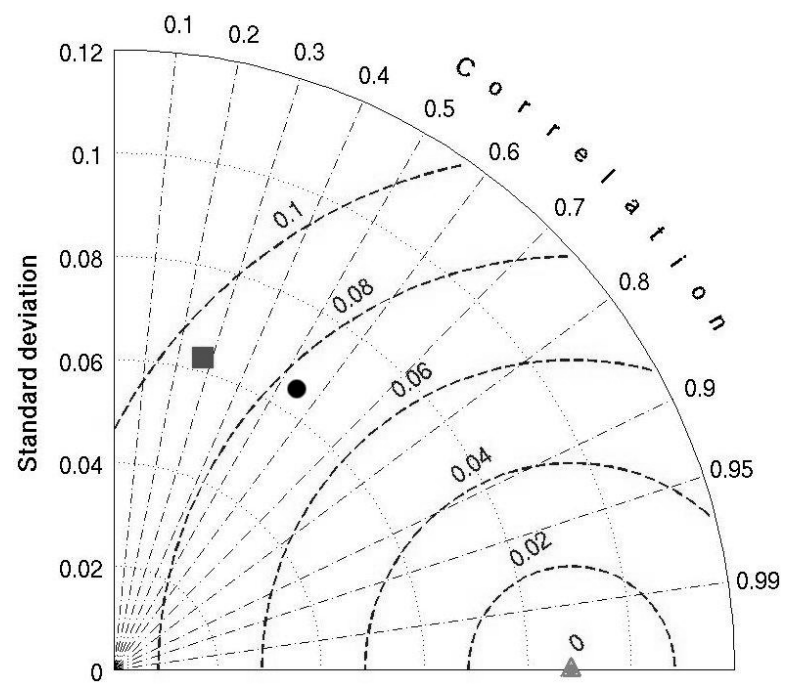

Figure 12 - Taylor diagram for SLA (m) from January $1^{\text {st }}$ to March $31^{\text {st }} 2011$ produced by the control run (rectangle) and the $24 \mathrm{~h}$ "forecast" of the assimilation run (circle) with respect to AVISO $1 / 3^{\circ}$ horizontal resolution gridded data (triangle). The blue dashed semi-circles represent the centered root mean squared error with respect to AVISO data.

Successful preliminary experiments have been done to assimilate SST into HYCOM with EnOI. Reynolds SST analyses with 
$1 / 4^{\circ}$ of horizontal resolution were assimilated and the overall error of the analysis in the HYCOM $1 / 4^{\circ}$ SST was about $0.5^{\circ} \mathrm{C}$. The assimilation of SST produced a large impact in the mixed layer temperature and it did not affect S or T below $300 \mathrm{~m}$. Other SST fields with higher resolution will be used in future assimilation experiments.

The next step in the development of the EnOI into HYCOM will be the realization of assimilation of T-S Argo profiles, alongtrack SLA data and SST in a relatively short integration window, around 6 or $12 \mathrm{~h}$. Also, the codes are under parallelization to meet the needs of the operational system.

As mentioned above, other initiatives in data assimilation involve a version of the Kalman Filter into HYCOM and the 4D-Var into ROMS. The former was proposed by Belyaev et al. (2001). It uses the Fokker-Planck equation in the formulation to calculate the Kalman Gain matrix. The model error co-variance matrix in this approach is estimated from the joint probability density distribution of the errors among two observational points and from the solution of the Fokker-Planck equation, assuming that the model error is a stochastic diffusive variable. The feasibility, applications and limitations of this scheme are discussed in Tanajura \& Belyaev (2002, 2009). Application into HYCOM including a comparison with an Ensemble Kalman Filter and a simplified Ol is shown in Belyaev et al. (2012).

Assimilation into ROMS under REMO will get momentum in 2013 with planned experiments of 4D-Var scheme. It is also planned for the future that the EnOI code used into HYCOM would be adapted to ROMS. The initial experiments will use a sub-grid extracted from the ROMS $1 / 24^{\circ}$ model off the Brazilian south-southeast coast. The 4D-Var is already available with ROMS (Moore et al., 2011), but its realization is not trivial, since its formulation and algorithm are quite complex and the computational cost is high. International collaboration in the framework of GODAE OceanView is under way to promote a solid and fast development of assimilation into ROMS.

\section{REMOTE SENSING AND OCEANOGRAPHIC OBSERVATIONS}

As previously discussed in the design of REMO forecasting system, an important task group is related with sea surface remote sensing and oceanographic observations. Regarding remote sensing, efforts have been concentrated on developing routine methodologies to estimate SST and SSH fields using available data from environmental satellites. Presently, the estimated SST fields via remote sensing have high standards, how- ever, there is a problem associated with cloud coverage, which is still a challenge for generating clear images to identify oceanographic features in tropical and equatorial regions with an extensive cloud coverage rate. In order to minimize the cloudcontaminated pixels in the SST field, REMO remote sensing specialists developed a cloudy free SST composition method to generate a daily blended (infrared and microwave) SST in a regular horizontal grid $\left(0.05^{\circ}\right)$. The merge (or composition) of SST AVHRR (Advanced Very High Resolution Radiometer) data with spatial horizontal resolution of $0.081^{\circ}$ - from NOAA satellites series and SST TMI (Microwave Imager) data from TRMM (Tropical Rainfall Measuring Mission) - with spatial horizontal resolution of $0.25^{\circ}$ - is based on Barnes Objective Analysis (OA) method (Barnes, 1964). The main steps of the methodology are extracting SST data and removing noise, selecting cloud-free SST values for a specified continuous time period (it has been used 24 hours), applying the OA, land masking; and systematically validating the remote SST results against in situ SST data. Figure 13 presents an example of the SST field composition (AVHRR and TMI) for REMO'S METAREA V modeled region.

REMO'S SST composition algorithm has achieved very good results. Statistic parameters such as the RMSE (Root Mean Squared Error), MAE (Mean Absolute Error), MBE (Mean Bias Error), CORR (Correlation) have been used to evaluate composed fields against in situ SST (at approximately 1.0-m depth) from five PIRATA buoys. Results for the period August $1^{\text {st }}, 2005$ to July $31^{\text {st }}, 2006$, are presented in Table 2.

Table 2 - RMSE, MAE, MBE and CORR statistics for comparison of estimated fields versus in situ SST (1-m depth) at five PIRATA buoy sites from Aug. 2005 to Jul. 2006.

\begin{tabular}{|c|c|c|c|c|}
\hline Buoy location & RMSE & MAE & MBE & CORR \\
\hline $0^{\circ} \mathrm{N}-35^{\circ} \mathrm{W}$ & 0.24 & 0.19 & -0.04 & 0.93 \\
$0^{\circ} \mathrm{N}-23^{\circ} \mathrm{W}$ & 0.30 & 0.24 & -0.16 & 0.98 \\
$8^{\circ} \mathrm{S}-30^{\circ} \mathrm{W}$ & 0.19 & 0.15 & -0.06 & 0.98 \\
$14^{\circ} \mathrm{S}-32^{\circ} \mathrm{W}$ & 0.32 & 0.25 & -0.16 & 0.97 \\
$1^{\circ} \mathrm{S}-34^{\circ} \mathrm{W}$ & 0.29 & 0.23 & -0.10 & 0.99 \\
\hline
\end{tabular}

Concerning data assimilation on ocean modeling, sea surface altimetry data play an important hole as they provide relevant information about ocean dynamics. Currently, as of our knowledge, there are no free publically available near-real time altimetric data with all required filtering, homogenization and specific geophysical and atmospheric corrections required to provide a high standard product to be directly assimilated into 

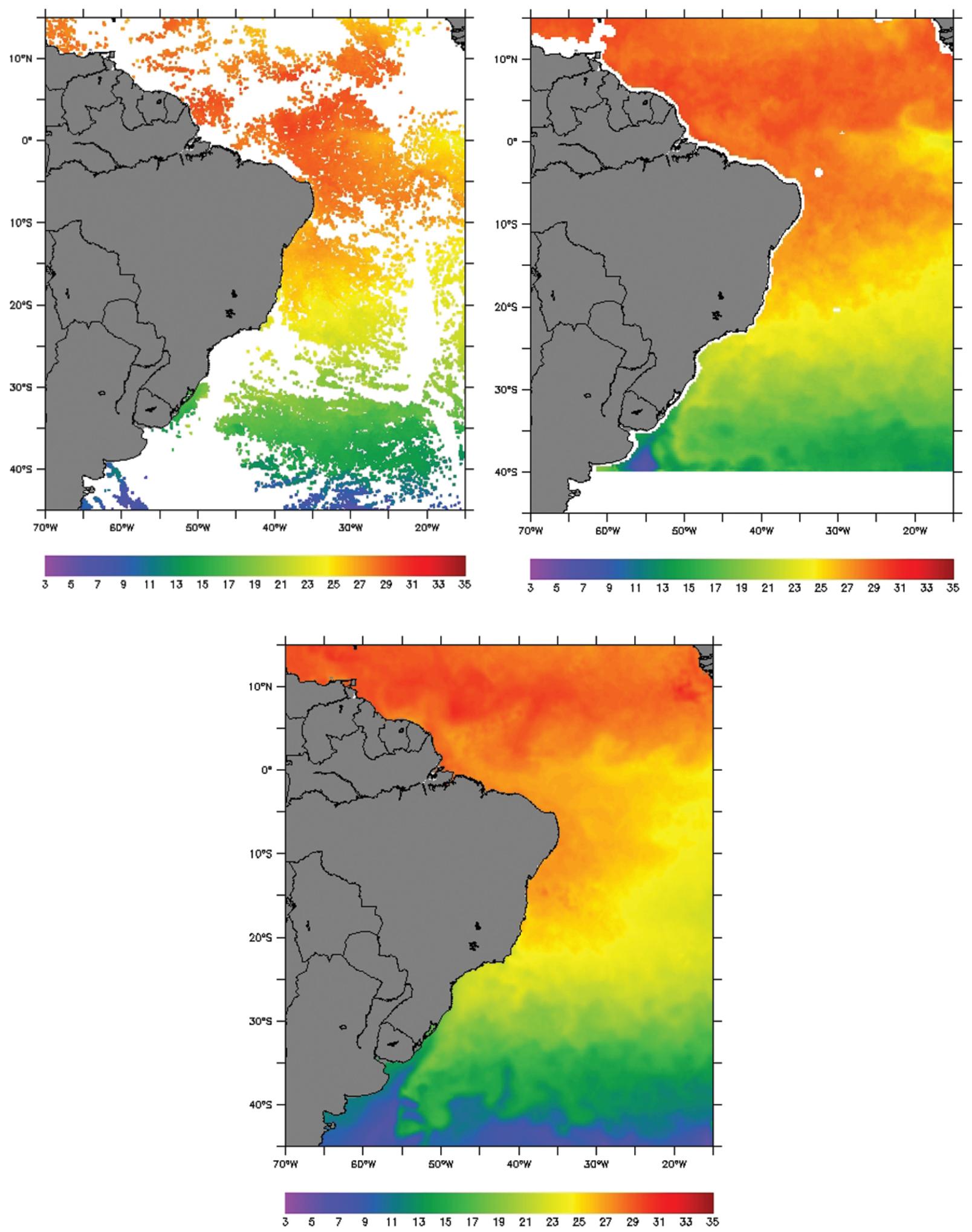

Figure 13 - The cloud-free SST composition (lower central panel) is obtained using AVHRR SST (upper left panel) and TMI SST (upper right panel). This example image is from July 11th, 2010. 
numerical ocean models with accuracy levels that would permit full resolution of detailed meso-scale phenomena in the western South Atlantic Ocean. REMO's remote sensing specialists are pursuing to develop near-real time routines for establishment of a solid and reliable SSH framework for data assimilation purposes. As on-going research, a joint project was established with French research company Collect Localisation Satellites (CLS) to develop an along-track sea level anomaly (SLA) product level 3 and gridded SLA product oriented to some regions of the Brazilian shelf and ocean border, in order to fulfil assimilation and assessment needs of the models. This project is called ATOBA, an acronym for "Altimetry Tailored and Optimised for Brazilian Applications".

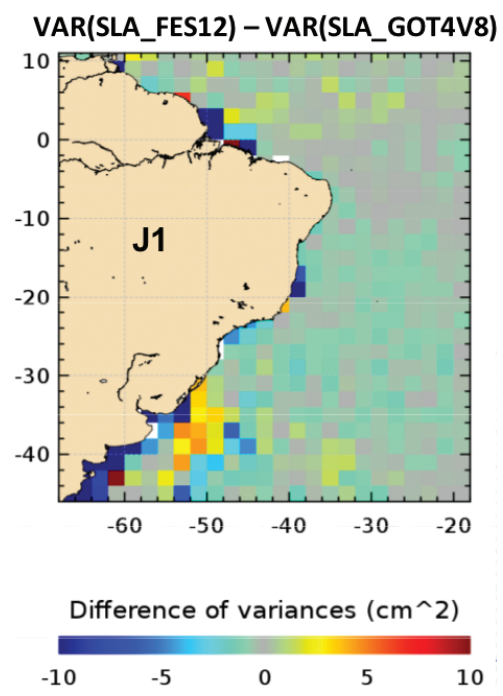

Figure 14 - Difference of variance of the SLA estimated by FES2012 and GOT4V8 tidal models. This is a product of the cooperation project ATOBA between REMO and CLS.

Within the cooperative framework of this project, it has been done studies to refine along-track filtering and sub-sampling, evaluation and choice of atmospheric (wet troposphere) and geophysical (ocean tides) corrections, and validation to improve the along-track SLA data. Concerning the gridded data product, the choice of adaptative time and space scales for Objective Analysis has been reviewed. One of the Brazilian regional products uses tides estimated by FES2012 model (Carrère et al., 2012) as ocean tidal corrections. The comparison between FES2012 and G0T4V8 that is used in the Ssalto/DUACS SLA data processing can be seen in Figure 14. This result shows that FES2012 reduces the SLA variance near the coast, what represents better ocean tidal corrections. Figure 15 presents spectra comparison between along-track SLA from ATOBA and Ssalto/DUACS available at AVISO website. The filtering tech- nique used in ATOBA data processing can better preserve the meso-scale signals.

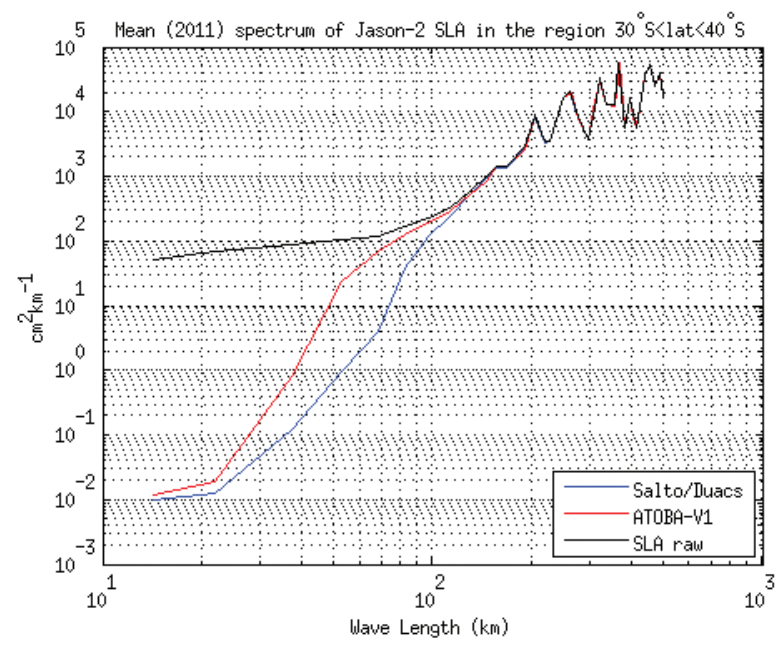

Figure 15 - Comparison of the mean spectrum of Jason-2 SLA against Salto/Duacs and ATOBA-V1 data processing in the South Atlantic region between latitudes $30^{\circ} \mathrm{S}$ and $40^{\circ} \mathrm{S}$.

Another important component of any oceanic forecasting system is an available network of data measurement stations that would provide information to be assimilated or to evaluate model results. This is a critical component because it requires expensive resources as metocean equipment, oceanographic vessels, and specialized personnel to deploy and recover moorings and metocean buoys. There are already some ongoing initiatives of continuous oceanographic measurements in the Brazilian border of South Atlantic ocean, such as the PIRATA (Bourlès et al., 2008) and the PNBOIA (portuguese acronym for "Programa Nacional de Boias"), both programs with participation of CHM. REMO is collaborating to improve and maintain metocean equipment of existing PNBOIA buoys, and deploying other buoys and moorings that would provide oceanographic information on two critical capes of southeast Brazilian shelf: Cabo de São Tomé and Cabo Frio. Silveira et al. (2008) describe instabilities of the $B C$ in this region and show that vorticity waves associated with $B C$ meandering along the shelf break is one of the mechanisms associated with large eddy growth on São Tomé and Cabo Frio capes. Two pairs of mooring are designed to be deployed on this region to provide information to be assimilated in the oceanic models with objective to improve forecasting capability of meso-scale activity. Figure 16 shows locations of metocean buoys and moorings with REMO collaboration. It is also presented some proposed transects for gliders or XBTs deployment. Table 3 presents their existing or planned configurations. 


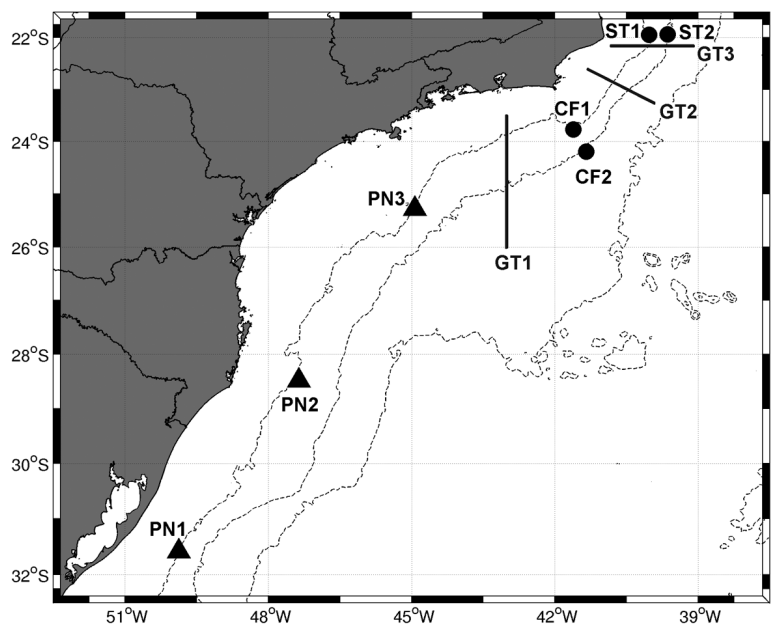

Figure 16 - Oceanographic measurements with REMO collaboration for the $S$ SE Brazilian ocean border: metocean buoys PN1, PN2 and PN3 from PNBOIA (triangles), moorings from UFRJ (circles) and proposed gliders or XBTs transects GT1, GT2 and GT3 (solid blue lines).

It should also be pointed out that the four planned moorings to be deployed by UFRJ with REMO funding will be equipped with metocean surface buoys designed and manufactured in Brazil, denominated BMO-BR (Mendes et al., 2011) as presented in Figure 17. High costs associated with purchasing, operating and maintaining foreign built oceanographic equipment in Brazil is one of the main problems that limits widespread use of these ocean observing systems. REMO is pursuing to use equipment with low operative costs. The $2.5 \mathrm{~m}$ diameter BMO-BR hull was also designed to measure surface gravity waves and field tests were already done with good results. This is another positive action of the REMO consortium to improve physical oceanographic sciences in Brazil.

\section{CONCLUDING REMARKS}

This paper outlined various aspects associated with design and implementation of the REMO modeling consortium, a Brazilian initiative on operational ocean forecasting and physical oceanography. As presented in previous sections, initial results are very promising because they bring together expertise of all involved institutions. The main goal of developing numerical ocean models with assimilative skills for the South Atlantic basin and Brazilian continental shelf is being closely pursued.

Design of the development, observational and operational phases were carefully discussed among participants in such a way that REMO would consolidate a reliable and long-term initiative with significant contributions of Brazilian Navy, universities, and interested public and private partners that would like to contribute to this project. The main problems associated with lack of expe- rienced specialists on ocean forecasting, adequate computational resources for operational purposes and lack of in situ observations are gradually being worked out. The pathway for that has been achieved by:

i) training graduate students at participant universities;

ii) improving computational resources by installing HighPerformance Computers (HPC) at universities and CHM;

iii) gradually mounting an observational network to provide metocean data for assimilation and model evaluation purposes.

While the practical aspects of ocean forecast are kept in mind, and are considered as a desirable forthcoming goal, special emphasis in REMO is also put in academic and scientific oriented studies. Some of the issues that should be under future investigation are: surface thermodynamic forcing feedback and its importance in setting the baroclinic structure of the upper ocean, connection to deeper layers through subduction and ventilation of the thermocline, effects of meso-scale processes upon large scale aspects of the circulation and climate variability, eddy-current and eddy-topography interactions in the Brazil Current and their impact on eddy development and translation, open boundary forcing, and data quality control for assimilation purposes.

The complex flow of the Brazil Current with its meanders and eddies along the continental slope is very difficult to accurately forecast, because it requires better estimates of the SLA fields close to the shelf break along the western border of the South Atlantic Ocean. REMO's remote sensing task group is strongly pursuing to improve the quality of SLA estimates for this region of the Brazilian shelf in order to increase the skills of altimetry assimilation in our operational models. For the modeling stand point, efforts are concentrated on testing a new higher horizontal and vertical resolution grid for the Atlantic Basin domain extending the western boundary into the Indian Ocean in order to properly solve the contribution of Agulhas eddies. This model will be fully assimilative using an EnOl data assimilation scheme for both surface SLA and SST fields and sub-surface T\&S fields.

It is expected that ongoing work under REMO will be an effective contribution to operational oceanography in Brazil, and on an international level, collaboration with the GODAE OceanView project. The operational models results can be accessed on web sites <http://www.mar.mil.br/dhn/chm/meteo/prev/modelos $>$ or $<$ http://www.rederemo.org $>$, the last site also presents informa- 
Table 3 - Configuration of existing and planned oceanographic measurements with REMO collaboration.

\begin{tabular}{|c|c|c|c|}
\hline Index & Location & Depth & \multicolumn{1}{c|}{ Measurements } \\
\hline ST1 & Upper slope Cabo São Tomé & $300 \mathrm{~m}$ & meteoro, Iong range current and T profile \\
\hline ST2 & Offshore Cabo São Tomé & $200 \mathrm{~m}$ & meteoro, long range current and T profile \\
\hline CF1 & Upper slope Cabo Frio & $300 \mathrm{~m}$ & meteoro, long range current and T profile \\
\hline CF2 & Offshore Cabo Frio & $2000 \mathrm{~m}$ & meteoro, long range current and T profile \\
\hline PN1 & PNBOIA buoy Rio Grande & $200 \mathrm{~m}$ & wave, meteoro, short range current profile \\
\hline PN2 & PNBOIA buoy Santa Catarina & $200 \mathrm{~m}$ & wave, meteoro, short range current profile \\
\hline PN3 & PNBOIA buoy Santos & $200 \mathrm{~m}$ & wave, meteoro, short range current profile \\
\hline GT1 & Pre-Salt Santos Basin transect & $100 \mathrm{~m}-2500 \mathrm{~m}$ & T and S profiles \\
\hline GT2 & Campos Basin transect & $100 \mathrm{~m}-2500 \mathrm{~m}$ & T and S profiles \\
\hline GT3 & Cabo de São Tomé transect & $100 \mathrm{~m}-2500 \mathrm{~m}$ & T and S profiles \\
\hline
\end{tabular}
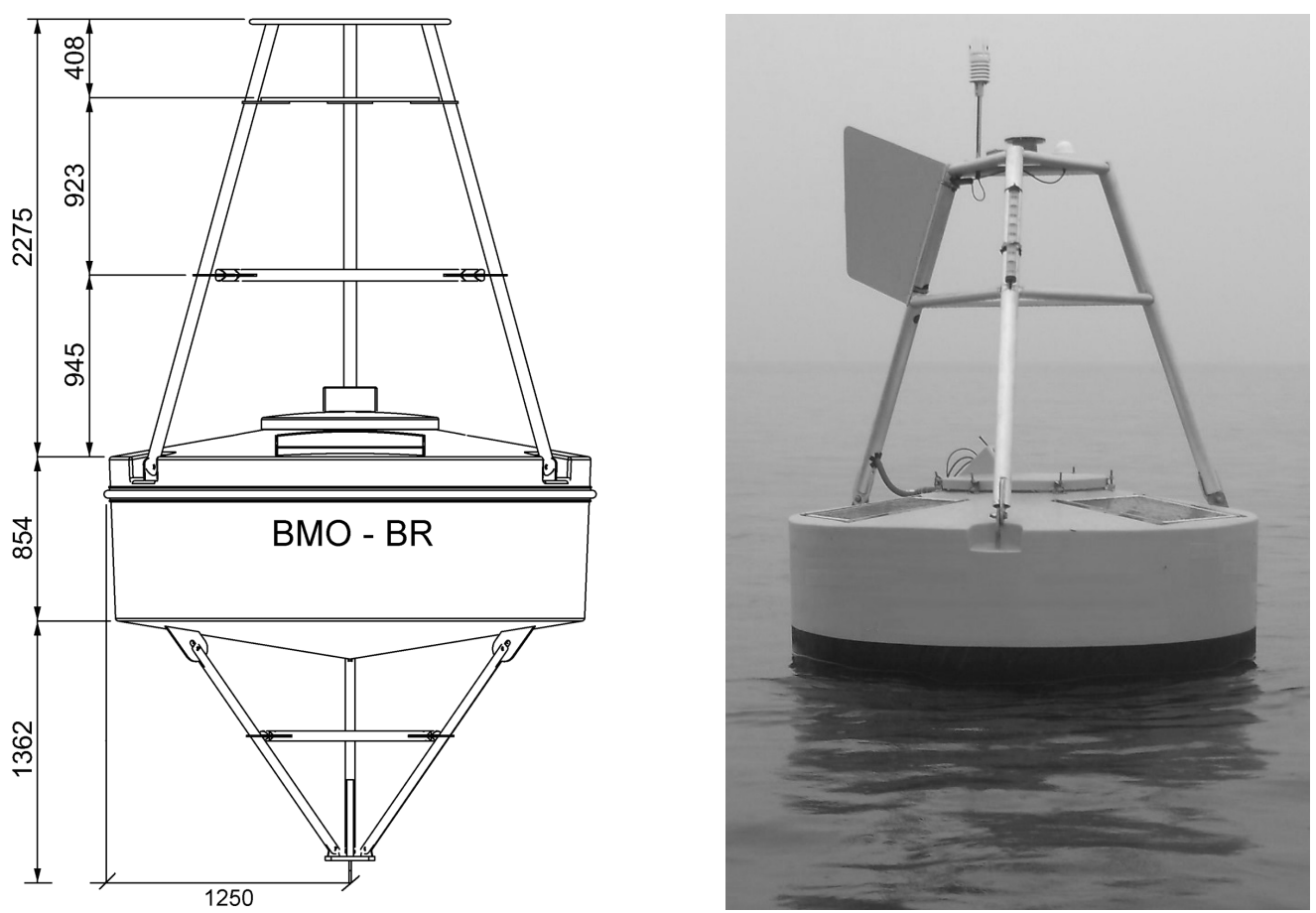

Figure 17 - Brazilian metocean buoy BMO-BR that will be used in REMO moorings. Left panel presents buoy dimensions and right panel is a first buoy under prototype field tests.

tion about participants, scientific publications and ongoing activities. The scientific results and products developed by REMO may reach a broad variety of scientists, students and general users of oceanographic information so that other applications can become feasible to promote benefits to the Brazilian society. New participants are encouraged to participate in the network contributing with their expertise to improve results, joining the scientific group REMO through the site that catalogs the directory of Brazilian research groups. This is an initiative of the Conselho Nacional de Desenvolvimento Científico e Tecnológico (CNPq).

As final remark, one of the main aspects of any oceanographic operational system is its sustainability because it requires expensive and continuous resources, such as HPC facilities, specialized researchers to operate the models and vessels to deploy and recover metocean equipment. It is not reasonable to believe that a single funding source would be able to maintain such complex systems over a long period of time, covering all operational 
oceanography needs of an extensive ocean region as the Brazilian territorial waters, also called the "Blue Amazon". REMO is open to share its developed products and receive funding contributions from public partners (interested ministries and governmental institutions), as well as from private companies from sectors that would greatly benefit from the use of operational oceanography products, such as oil \& gas operators, offshore services, navigation, fisheries, etc. The capability to provide useful products to distinct partners will probably be the most important point to build up a funding framework to maintain REMO over a mid or long time frame, as well as being of direct benefit to Brazilian scientific knowledge over its territorial waters.

\section{ACKNOWLEDGMENTS}

The authors would like to acknowledge Petróleo Brasileiro S.A. PETROBRAS for providing research funds and Agência Nacional do Petróleo, Gás Natural e Biocombustíveis (ANP) for their approval. The Brazilian Navy also provided useful resources, such as the labour of specialized officers, a spacious building for researchers and additional computational power. Participant universities (UFRJ, UFBA, USP and FURG) provided researchers with valuable expertise. More than 50 researchers have collaborated with REMO over the last six years. Nowadays they are about 25. We would appreciate to explicitly thank all of them, but unfortunately, it is not possible to name them all here. We will choose the ones that have directly helped to build this article providing figures and comments: Marcelo Andrioni (CENPES), Leonardo Lima and Davi Mignac (UFBA), Victor Daher (CHM), Claire Dufau (CLS) and Rosa Paes, Mariela Gabioux and Vladimir Costa (UFRJ).

\section{REFERENCES}

AMORIM FN, CIRANO M, MARTA-ALMEIDA M, MIDLETON JF \& CAMPOS EJD. 2013. The Seasonal Circulation of the Eastern Brazilian Shelf between $10 S$ and $16 \mathrm{~S}$ : a modeling approach. Continental Shelf Research, 65: $121-140$.

ANP - AGÊNCIA NACIONAL DO PETRÓLEO, GÁS NATURAL E BIOCOMBUSTíVEIS. 2013. Boletim da Produção de Petróleo e Gás Natural - Maio 2013. Boletim elaborado pela Superintendência de Desenvolvimento e Produção. 26 pp. Available on: <http://www.anp.gov.br/>. Access on: July 11, 2013.

BARNES S. 1964. A Technique for Maximizing Details in Numerical Weather Map Analysis. J. Appl. Meteor., 3: 395-409.

BELYAEV KP, TANAJURA CAS \& O'BRIEN JJ. 2001. A data assimilation method used with an ocean circulation model and its application to the Tropical Atlantic. Appl. Math. Modelling, 25: 655-670.
BELYAEV KP, TANAJURA CAS \& TUCHKOVA N. 2012. Comparison of methods for Argo drfiters data assimilation into a hydrodynamical model of the ocean. Oceanology, 52: 643-653.

BLECK R \& BOUDRA DB. 1981. Initial testing of a numerical ocean circulation model using a hybrid (quasi-isopycnic) vertical coordinate. J. Phys. Oceanogr., 11: 755-770.

BLECK R. 2002. An oceanic general circulation model framed in hybrid isopycnic-cartesian coordinates. Ocean Modelling, 37: 55-88.

BLUMBERG AF \& MELLOR GL. 1987. A description of a three-dimensional coastal ocean circulation model. In: HEAPS N (Ed.). Threedimensional ocean models. AM. Geophys. Union, 16 pp.

BOURLÈS B, LUMPKIN R, McPHADEN MJ, HERNANDEZ F, NOBRE P, CAMPOSE, YU L, PLANTON S, BUSALACCHI AJ, MOURA AD, SERVAIN $J$ \& TROTTE J. 2008. The PIRATA program: history and accomplishments of the 10 first years tropical Atlantic observing system's backbone. Bulletin of the American Meteorological Society, 89(8): 1111-1125.

BRASSINGTON GB. 2011. System Design for Operational Ocean Forecasting. In: SCHILLER A \& BRASSINGTON GB (Eds.). Operational Oceanography in the $21^{\text {st }}$ Century, Springer S+B Media B.V: 441-486.

BRYAN K. 1969. A Numerical Method for the Study of the Circulation of the World Ocean. Journal of Computational Physics, 4: 347-376.

CARRÈRE L, LYARD F, CANCET M, GUILLOT A \& ROBLOU L. 2012. FES2012: A new global tidal model taking advantage of nearly 20 years of altimetry. Proceedings of meeting "20 Years of Altimetry", Venice. 22 pp.

CHARNEY JG, FJORTOFT R \& VON NEUMANN J. 1950. Numerical integration of the barotropic vorticity equation. Tellus, 2: 237-254.

CLARK C, HARRISON D, JOHNSON M, BALL G, GONI G, WILSON S, BENVENISTE J, FELLOUS JL, GOHIL B, JACOBS G, LE TRAON P, LINDSTROM E, MINGSEN L, NAKAGAWA K \& PARISOT F. 2009. An overview of global observing systems relevant to GODAE. Oceanography, 22: 22-33.

COHN S. 1997. An introduction to estimation theory. J. Meteor. Soc. Japan, 75: 257-288.

COOPER M \& HAINES K. 1996. Altimetric assimilation with water property conservation. J. Geosphys. Res., 101 (C1): 1059-1077.

COSTA FILHO FH. 2005. Barracuda and Caratinga FPSO Design. Proceedings of the 2005 Offshore Technology Conference (OTC 2005). Paper number 17058, $7 \mathrm{p}$.

CUMMINGS J., BERTINO L, BRASSEUR P, FUKIMORI I, KAMACHI M, MARTIN MJ, MOGENSEN K, OKE P, TESTUT CE, VERRON J \& WEAVER A. 2009. Ocean data assimilation systems for GODAE. Oceanography, 22: 96-109.

DALEY R. 1991. Atmospheric data analysis. Cambridge University Press, Cambridge, $457 \mathrm{pp}$. 
DERBER J \& ROSATI A. 1989. A global data assimilation system. J. Phys. Oceanogr., 19: 1333-1347.

DOMBROWSKY E, BERTINO L, BRASSINGTON GB, CHASSIGNET EP, DAVIDSON F, HULBURT HE, KAMACHI M, LEE T, MARTIN MJ, MEI S \& TONANI M. 2009. GODAE systems in operation. Oceanography, 22(3): 80-95.

EVENSEN G. 2003. The ensemble Kalman filter: Theoretical formulation and practical implementation. Ocean Dyn., 53: 343-367.

EZER T \& MELLOR GL. 1994. Continuous assimilation of Geosat altimeter data into a three-dimensional primitive equation Gulf Stream model. J. Phys. Oceanogr., 24: 832-847.

EZER T \& MELLOR GL. 1997. Data Assimilation Experiments in the Gulf Stream Region: How Useful Are Satellite-Derived Surface Data for Nowcasting the Subsurface Fields. Jour. of Atmospheric and Oceanic Technology, 14: 379-1391.

GABIOUX M, COSTA VS, SOUZA JMA, OLIVEIRA BF \& PAIVA AM. 2013. Modeling the South Atlantic Ocean from medium to high resolution. Revista Brasileira de Geofísica, 31(2): 229-242.

GHIL M \& MALANOTTE-RIZZOLI P. 1991. Data assimilation methods in meteorology and oceanography. Adv. Geophys., 33: 141-266.

KALNAY E. 2003. Atmospheric modeling, data assimilation and predictability. Cambridge University Press, 341 pp.

LIMA JAM, RIBEIRO OR, CECOPPIERI W \& MATHESON GG. 2009. Directional extreme current profiles based on complex orthogonal functions (C_EOF) for offshore design. Proceedings of the ASME $28^{\text {th }}$ International Conference on Ocean, Offshore and Arctic Engineering (OMAE 2009). Paper number 79467,8 pp.

LIMA LN \& TANAJURA CAS. 2013. Estudo do impacto da assimilação de dados altimétricos na previsibilidade de curto-prazo do modelo oceânico HYCOM sobre a Metarea V do Oceano Atlântico. Revista Brasileira de Geofísica, 31(2): 271-288.

MELLOR GL \& EZER T. 1991. A Gulf Stream model and an altimetry assimilation scheme. J. Geophys. Res., 96: 8779-8795.

MENDES ALT, LIMA JAML, BARREIRA RA, PEREIRA RM, SOUZA L \& PIRES C. 2011. Desenvolvimento de uma boia-ondógrafo de projeto Nacional. Proceeding do XIV Congresso Latino-Americano de Ciências do Mar - XIV COLACMAR, Camboriú, SC, Brazil.

MOORE A, ARANGO H, BROQUET G, POWELL B, ZAVALA-GARAY J \& WEAVER A. 2011. The Regional Ocean Modeling system (ROMS) 4-dimensional variational data assimilation systems Part I: System overview and formulation. Prog. Oceanogr., 91: 34-49.

MOURA AD. 1996. Von Neumann e a previsão numérica de tempo e clima. Estudos Avançados [online]. 10 (26): 227-236. Available on: $<$ http://www.scielo.br/scielo.php?script=sci_arttext\&pid=S0103-
$40141996000100021 \& \operatorname{lng}=$ en\&nrm=iso $>$.

Access on: July 11, 2013.

OLIVEIRA JF. 2009. Um esquema de assimilação de dados oceanográficos para o modelo oceânico HYCOM ao largo da costa sudoeste brasileira. Ph.D. Thesis. Laboratório Nacional de Computação Científica (LNCC) 157 pp.

PAIVA AM, CHASSIGNET EP \& MARIANO A. 2000. Numerical simulations of the North Atlantic Subtropical Gyre: Sensitivity to boundary conditions. Dyn. Atmos. Oceans, 32: 209-238.

PAIVA AM \& CHASSIGNET EP. 2001. The impact of surface flux parameterizations on the thermodynamic adjustment of a North Atlantic ocean model. J. Phys. Oceanogr., 31(7): 1860-1879.

PAIVA AM, GABIOUX M, COSTA VS \& OLIVEIRA BF. 2012. Base Hidrodinamica SSE. Relatório do Grupo de Estudos de Processos Oceânicos, Área de Engenharia Costeira e Oceanográfica, Programa de Engenharia Oceânica, COPPE, UFRJ, 120 pp.

RICHARDSON LF. 1922. Weather prediction by numerical process. London, University Press. 236 p. apud. MOURA 1996.

SAKOV P, COUNILLON F, BERTINO L, LISAETER KA, OKE PR \& KORABLEV A. 2012. TOPAZ4: an ocean-sea ice data assimilation system for the North Atlantic and Arctic. Ocean Science, 8: 633-656.

SILVEIRA ICA, LIMA JAM, SCHMIDT ACK, CECCOPIERI W, SARTORI NETO A, FRANCISCO CPF \& FONTES RFC. 2008. Is the Meander Growth in the Brazil Current System off Southeast Brazil due to Baroclinic instability? Dynamics of Atmospheres and Oceans, 45: 187-207.

SHCHEPETKIN AF \& McWILLIAMS JC. 2005. The Regional Ocean Modeling System: a split explicit, free surface, topography following coordinates ocean model. Ocean Modelling, 9: 347-404.

SEMTNER AJ. 1995. Modeling Ocean Circulation. Science, 269: 13791385.

SMAGORINSKY J. 1983. The beginnings of numerical weather prediction and general circulation modeling: early recollections. Advances in Geophysics, 25: 3-37.

TANAJURA CAS \& BELYAEV KP. 2002. On the oceanic impact of a data assimilation method on a coupled ocean-land-atmosphere model. Ocean Dynamics, 52: 123-132.

TANAJURA CAS \& BELYAEV KP. 2009. A sequential data assimilation method based on the properties of diffusion-type process. Appl. Math. Model., 33: 2165-2174.

TANAJURA CAS, COSTA FB, SILVA RR, RUGGIERO GA \& DAHER VB. 2013. Assimilation of sea surface height anomalies into HYCOM with an Optimal Interpolation scheme over the Atlantic Ocean Metarea V. Revista Brasileira de Geofísica, 31(2): 257-270.

WEAVER AT, VIALARD J \& ANDERSON DLT. 2003. Three- and four-dimensional variational assimilation with a general circulation models of 
the tropical Pacific Ocean. Part I: Formulation, internal diagnostics and consistency checks. Mon. Wea. Rev., 131: 1360-1378.

XIE J \& ZHU J. 2010. Ensemble optimal interpolation schemes for assimilating Argo profiles into a hybrid coordinate ocean model. Ocean
Modelling, 33: 283-298.

XIE J, COUNILLON F, ZHU J \& BERTINO L. 2011. An eddy resolving tidal-driven model of the South China Sea assimilating along-track SLA data using the EnOI. Ocean Science, 7: 609-627.

\section{NOTES ABOUT THE AUTHORS}

Jose Antonio Moreira Lima is a mechanical engineer with M.Sc. in Ocean Engineering by Universidade Federal do Rio de Janeiro (UFRJ) and Ph.D. in Physical Oceanography by the School of Mathematics, University of New South Wales, Australia. Senior metocean specialist at Petrobras Research and Development Center, and works with oceanographic data analysis, development and application of ocean numerical models and metocean design criteria.

Renato Parkinson Martins is a civil engineer with M.Sc. and Ph.D. in Ocean Engineering by Universidade Federal do Rio de Janeiro (UFRJ). Is an environmental engineer at Petrobras Research and Development Center, Rio de Janeiro, Brazil. Previously worked as a Professor for the Universidade do Estado do Rio de Janeiro (UERJ), and presently works with development and application of ocean numerical models, environmental studies and metocean data processing.

Clemente Augusto Souza Tanajura is mechanical-nuclear engineer with Ph.D. in Meteorology by the University of Maryland. Was an Associate Researcher for the Brazilian National Laboratory for Scientific Computing (LNCC) for 18 years and today is a Professor for the Universidade Federal da Bahia (UFBA). He was the scientific-technological coordinator of REMO and leader of the REMO research group in CNPq from December 2008 until March 2013. Currently is a member of the GODAE OceanView Science Team, and works with data assimilation, ocean and atmosphere modeling, and climate studies.

Afonso de Moraes Paiva is an oceanographer with M.Sc. in Ocean Engineering by Universidade Federal do Rio de Janeiro (UFRJ) and Ph.D. in Physical Oceanography by the University of Miami. Is a Professor for the Ocean Engineering Program at the Institute Alberto Luiz Coimbra for Graduate Studies and Research in Engineering (COPPE), Universidade Federal do Rio de Janeiro. Is one of the leaders of the Research Group REMO at CNPq, and studies ocean processes using numerical models and observational data.

Edmo Campos has a Degree and M.Sc. in Physics by the Universidade de Brasília and Ph.D. in Physical Oceanography by the University of Miami. Is Professor and Head of the Dept. of Physical, Chemical and Geological Oceanography at the Instituto Oceanográfico da Universidade de São Paulo (IOUSP) and Adjunct Professor at University of Miami. Is a member of the Brazilian Academy of Sciences, and studies ocean processes using numerical models and oceanic observations.

Ivan Dias Soares is an oceanographer with M.Sc. in Physical Oceanography by the Universidade de São Paulo and Ph.D. in Physical Oceanography by the University of Miami. Was a Professor at the Universidade Federal do Rio Grande (FURG) for sixteen year, and now works as Senior Research Scientist for Instituto SINTEF do Brasil. Works with development of numerical ocean models and applied physical oceanography.

Mauro Cirano is an oceanographer with M.Sc. in Physical Oceanography by the Universidade de São Paulo and Ph.D. in Physical Oceanography by the School of Mathematics, University of New South Wales, Australia. Is a Professor for the Universidade Federal da Bahia (UFBA) and one of the leaders of the REM0 Research Group in CNPq for tasks associated with regional modeling. Studies coastal and ocean processes using numerical models and observational data.

Gutemberg Borges França has a degree in Physics at the Universidade Federal do Mato Grosso do Sul (UFMS), M.Sc. in Applied Computation at Instituto Nacional de Pesquisas Espaciais (INPE) and PhD in Remote Sensing at University of Dundee, United Kingdom. Is a Professor for the Meteorology Department at Universidade Federal do Rio de Janeiro (UFRJ) and Coordinator of the Applied Meteorology Laboratory (LMA). Works with development of remote sensing products using environmental satellites data.

Rodrigo de Souza Obino is an officer of the Brazilian Navy, specialized in the areas of Hydrography and Oceanography. Graduated by the School of Navy Studies of the Brazilian Navy, and has a M.Sc at the Naval Postgraduate School, Monterey, USA. Was one of the leading collaborators of REMO at the Centro de Hidrografia da Marinha (CHM) during his term as head of the Numerical Prediction Division.

João Bosco Rodrigues Alvarenga is a retired officer of the Brazilian Navy, specialized in the areas of Numerical Weather Forecasting and Ocean Modeling. Graduated by the School of Navy Studies of the Brazilian Navy, and has a M.Sc. in Physical Oceanography at Universidade de São Paulo (USP). Is the leader of a specialized group that is responsible for daily operation of the REMO ocean models at the Centro de Hidrograpfia da Marinha (CHM). 